\section{CELEBRATING MACROMOLECULAR CRYSTALLOGRAPHY: A PERSONAL PERSPECTIVE}

\author{
Celerino Abad-Zapatero \\ University of Illinois at Chigaco \\ caz@uic.edu
}

\section{CELEBRANDO LA CRISTALOGRAFÍA MACROMOLECULAR: UNA PERSPECTIVA PERSONAL}

Citation/Cómo citar este artículo: Abad-Zapatero, C. (2015). "Celebrating Macromolecular Crystallography: A Personal Perspective". Arbor, 191 (772): a215. doi: http://dx.doi. org/10.3989/arbor.2015.772n2001

Received: September 12, 2014. Accepted: February 13, 2015.
Copyright: (C) 2015 CSIC. This is an open-access article distributed under the terms of the Creative Commons Attribution-Non Commercial (by-nc) Spain 3.0 License.
ABSTRACT: The twentieth century has seen an enormous advance in the knowledge of the atomic structures that surround us. The discovery of the first crystal structures of simple inorganic salts by the Braggs in 1914, using the diffraction of X-rays by crystals, provided the critical elements to unveil the atomic structure of matter. Subsequent developments in the field leading to macromolecular crystallography are presented with a personal perspective, related to the cultural milieu of Spain in the late 1950's. The journey of discovery of the author, as he developed professionally, is interwoven with the expansion of macromolecular crystallography from the first proteins (myoglobin, hemoglobin) to the 'coming of age' of the field in 1971 and the discoveries that followed, culminating in the determination of the structure of the ribosomes at the turn of the century. A perspective is presented exploring the future of the field and also a reflection about the future generations of Spanish scientists.

KEYWORDS: crystallographic education; crystallography; history of macromolecular crystallography; international year of crystallography; origins of virus crystallography; Spanish education; Spanish research.
RESUMEN: El siglo XX ha sido testigo del increíble avance que ha experimentado el conocimiento de la estructura atómica de la materia que nos rodea. El descubrimiento de las primeras estructuras atómicas de sales inorgánicas por los Bragg en 1914, empleando difracción de rayos $X$ con cristales, proporcionó los elementos clave para alcanzar tal conocimiento. Posteriores desarrollos en este campo, que condujeron a la cristalografía macromolecular, se presentan aquí desde una perspectiva personal, relacionada con el contexto cultural de la España de la década de los 50. La experiencia del descubrimiento científico, durante mi desarrollo profesional, se integra en el desarrollo de la cristalografía macromolecular, desde las primeras proteínas (míoglobina y hemoglobina), hasta su madurez en 1971 que, con los posteriores descubrimientos, culmina con la determinación del la estructura del ribosoma. Asimismo, se explora el futuro de esta disciplina y se reflexiona sobre el futuro de las próximas generaciones de científicos españoles.

PALABRAS CLAVE: año internacional de la cristalografía; cristalografía; enseñanza de la cristalografía; educación en España; historia de la cristalografía macromolecular; investigación en España. 


\section{INTRODUCTION}

The celebration of the International Year of Crystallography (IYCr2014) has prompted a myriad of activities by institutions ranging from the pioneers (Royal Institution, UK) down to local universities and colleges in an extraordinary effort to promote the science and impact of crystallography. Historical perspectives as well as memories of the early practitioners have been presented at meetings and written in journals of different levels boasting the number of Nobel Prize winners in all branches of sciences related to crystallography (Biochemistry, Material Sciences, Drug Discovery among others). The same activity has been shown in covering specific areas of crystallography. Perspectives as well as memories of the early practitioners have been presented at different venues and the impact of crystallography in various sciences (material sciences, quasi-crystals, drug design and medicinal chemistry, biotechnology and macromolecular crystallography among others) has been amply discussed. This perspective will not attempt to cover all of these accomplishments. The prism of this perspective will be to present the developments of macromolecular crystallography from a personal viewpoint as they related to the personal development of the author as a scientist.

Unfortunately, many of the exciting scientific discoveries related to the origin of modern crystallography, from the discovery of X-rays by Roentgen in 1895 to the unveiling of the first simple chemical structures (i.e. $\mathrm{NaCl}$ ) by the Braggs (W.H. and W.L. father and son) in 1914, happened 'very far' away from Spain. I purposely used the 'very far' expression to highlight the fact that these scientific events happened at a great distance physically and intellectually. Although there was a rebirth of interest in science, scientific activities, and research during the years of the Republic, the scientific isolation of Spain during the years that General Francisco Franco was in power, (1936-1975) was rather extreme particularly in the early years. In the late 1950's and 1960's, when the children born after the Spanish Civil war reached adulthood, there appeared to be a window of opportunity for those individuals, particularly the middle class, to access the university classrooms and consider science (or even research!) as a possible option in their professional lives. The majority were trained to occupy the new university positions that became available as the Spanish society expanded culturally, but some wanted to look further beyond, and indeed wanted to look outside and see what science could be done beyond the borders of Spain, and even participate in the exciting discoveries of the time.
This perspective reflects on the thoughts, experiences and modest contributions of one of those individuals, intertwined with the extraordinary achievements and developments in macromolecular crystallography. This is the area of crystallography that has provided the scientific and biomedical community with an unimaginable richness of atomic detail about the molecules that make life possible. The different sections of this review will highlight the advances in the fields of biochemistry, molecular biology and structural biology as seen from the perspectives of the author and of the events that shaped his path to become a professional scientist. A final section will reflect onto the implications for the future generations of scientists in Spain.

\section{CRYSTALLOGRAPHY AS PART OF GEOLOGY}

Access to secondary education (Institutos de Enseñanza Media) was a critical step required to enable the generations born after the Civil War to reach the university classrooms. At the time, Spain was mainly a rural society, with the physical and educational infrastructure severely damaged by the war; not many small to middle size towns had those resources. I was particularly lucky in that the place where I was born, Aranda de Duero (province of Burgos), had an excellent Instituto built in 1928. In addition, the family environment was certainly appreciative and dedicated to education. My father was a schoolteacher who had recently been employed by the local catholic parish to head the parochial school of Santa María. He had many years of experience in many small state schools around my birthplace, where he used to go by bicycle, but the opportunity to come to a larger town, where my mother's family was and with more educational options for the children could not be dismissed (see Figure 1).

Thus, I entered the Instituto de Enseñanza Media of my hometown after a rigorous entry exam in 1957. The level of the different classes was high, although the emphasis was on memorization more than creative work. Nonetheless, we were exposed to an enormous amount of material in different subject matters: Art, French (Foreign Language), Latin, Geography, Mathematics, Chemistry and Physics, etc. This was particularly true of the later years (Bachillerato superior). Among the toughest courses of these years was a course of Natural Sciences, which encompassed mainly Geology and Biology as a preparation for teaching these subjects in high school. It was here that I was first exposed to 'crystallography' as a rather difficult part of Geology. We covered (and had to know) the mineral forms of many chemical species and also their symmetry forms. 
Figure 1. Corpus-Christi procession in Aranda de Duero, Burgos, Spain, circa 1956. The author is the altar boy located in the center of the first row of three. To the right of the group is his father, Don Juan Abad Barrasús, teacher and choir director. This image reflects the spirit and atmosphere of Spain about two decades after the end of the Civil War.

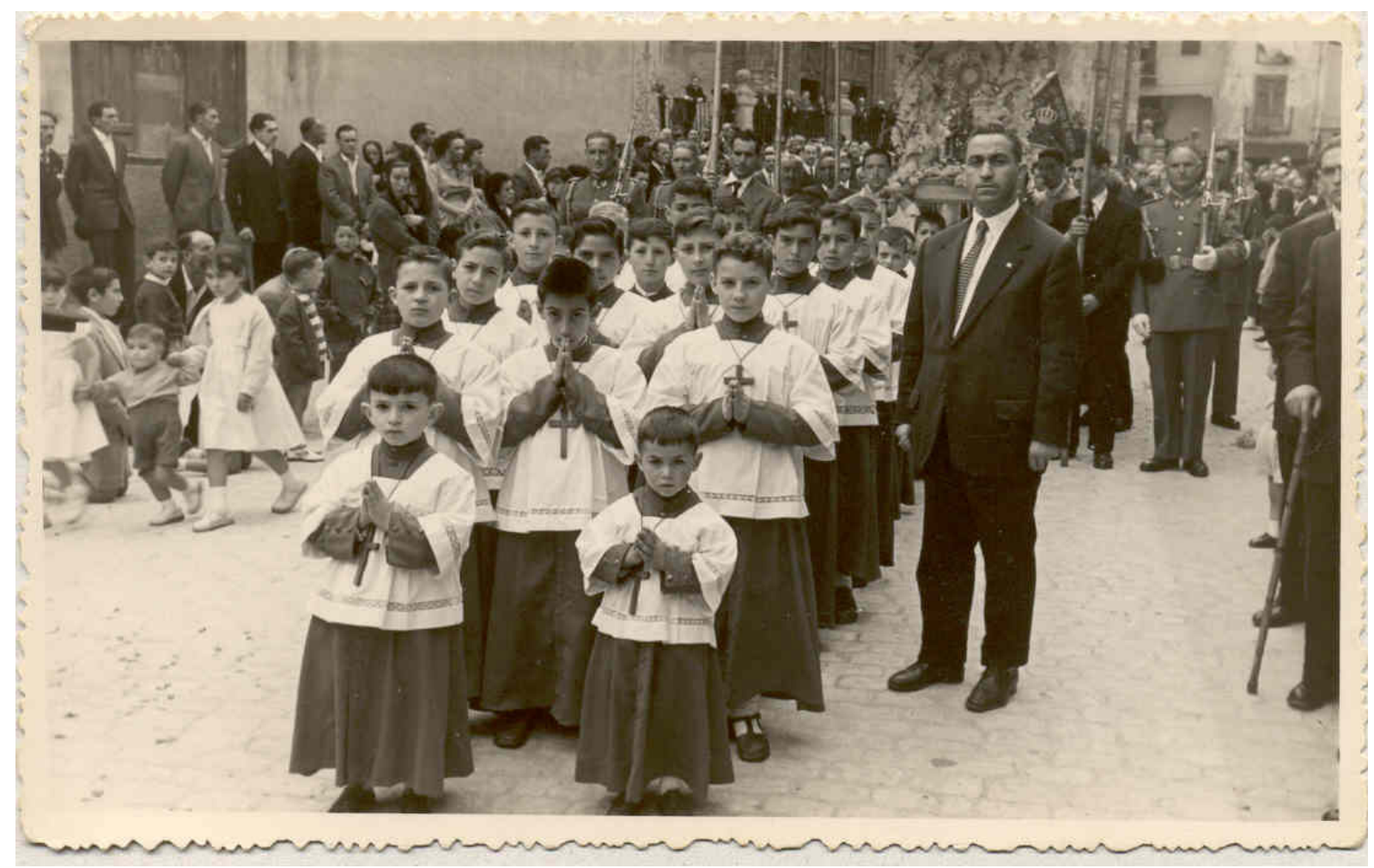

The teacher was outstanding, I warmly remember her name Ms. Victoria Serrano, and she explained to us the different symmetries of the crystals, the symmetry elements of each crystallographic form in rather cryptic notation. For instance, the symmetry elements of the holohedral form of the cubic system were: $3 A^{1 v}, 4 A^{\prime \prime \prime}$, $6 A^{\prime \prime}, 9-P$ and 1-C. Readers may recognize the formula as three 4-folds, four 3-folds, six 2-folds plus nine mirror planes and a center; the symmetry elements of a cube. Somehow, I understood all of this at the time and was able to show these symmetry elements when asked by the teacher. Most of my classmates couldn't do that. It just seemed natural and interesting. I have written about this memory in the Epilogue of my brief personal memoir (Abad-Zapatero, 2002a) ${ }^{1}$.

In addition, in the discussion about the properties of crystals, there was a sentence that is extremely relevant to the theme of this perspective. There was a quotation in the textbook for this course of Natural Sciences (authored by Salustio Alvarado), which referred to the historical experiment of Laue, Friedrich and Knipping that I can almost recite by heart: 'By exposing crystals to X-rays and obtaining a diffraction pattern, Laue and coworkers demonstrated at the same time, the wave nature of the $X$-rays and the periodic internal structure of the crystals'2 ${ }^{2}$ I certainly was able to repeat this statement but I was not quite sure what it meant. This was my first exposure to crystals and crystallography. Possibly, this first encounter stayed subconsciously in my psyche and ignited my future interest.

In my first year of studies at the University of Valladolid I had another interesting encounter with crystals and crystallography. During a Christmas break, I happened to spend countless hours assembling cardboard models of crystals for a Geology exam, when the reasonable thing to do would have been to go enjoy myself with my college friends or dating girls. Details can be found in the brief Epilogue of my intellectual journey ${ }^{3}$. Suffice it to say that after four more years of rigorous (although not very creative) study of Physics and Mathematics, I completed my degree ('Licenciado') in Physics in 1969 (see Figure 2). 
Figure 2. Iconic image ('Orla') of the graduating class of the Faculty of Physics of Valladolid in 1969. May this image serve as a small homage to the professors and a passing reference to my friends, colleagues and classmates of those years.

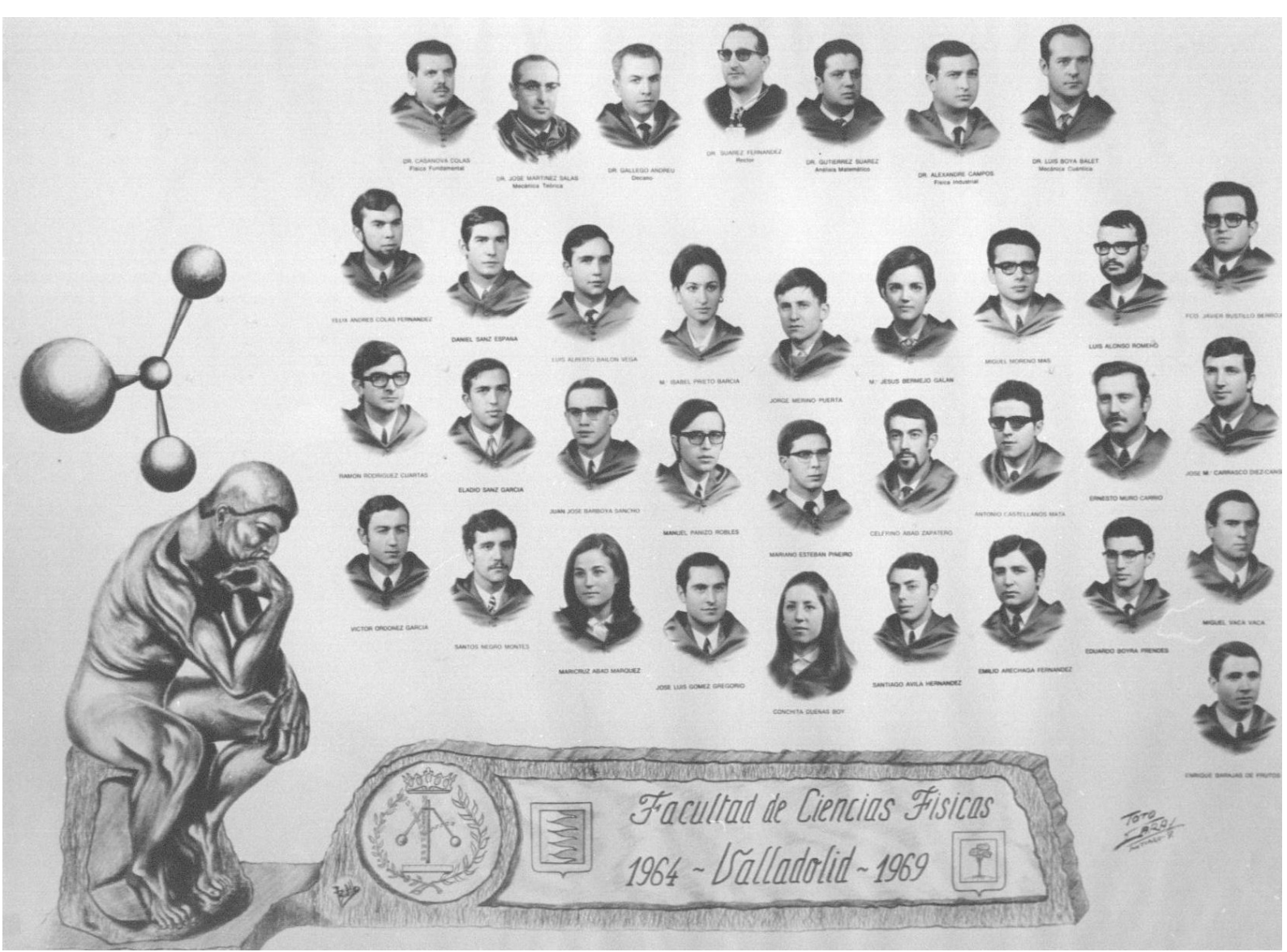

\section{FIRST CRYSTALS OF PROTEINS AND VIRUSES}

The question of what to do next after a university degree is always present in the minds and hearts of all college graduates. However, the question had unique tones in the late nineteen sixties in Spain, because of the situation and the cultural milieu that I hinted earlier. In Spain at the time, there was a strong perception of being intellectually isolated and not having many opportunities beyond the teaching positions at the expanding universities of the provinces of Spain, elsewhere from the major cities of Madrid, Barcelona, Bilbao and a few others.

Unbeknownst to us in the physical sciences and possibly to even the students of biology, a few dramatic breakthroughs had taken place in the world in the 1930's that opened the door to the amazing discoveries of structural biology in the second half of the $20^{\text {th }}$ Century.
In 1934, the dramatic observation of Bernal and Crowfoot regarding the critical role of moisture and solvent on the stability of protein crystals (Bernal and Crowfoot, 1934), provided the most valuable condition necessary to obtain the diffraction pattern from crystals of biological macromolecules (see Figure 3 ). Although it took almost thirty more years to materialize that observation into tangible structures, the door had been opened. Nowadays, crystals are frozen to provide extended diffraction data and durability in the X-ray beam.

The strong financial support of the Rockefeller Foundation and the commitment of W. L. Bragg and dedication of Max F. Perutz, John Kendrew, together with two teams of competent and dedicated coworkers, and the intellectual atmosphere of Cambridge made possible the determination of the first protein structures (hemoglobin, myoglobin) by the early 1960's. 
Figure 3. Early protein crystal mounting. A modern rendering of the strategy to mount protein crystals developed by J. D. Bernal that maintains the crystals moist in the presence of the mother solution as they are exposed to X-rays. Although it might appear simple, this insight cleared the path to the high quality diffraction and eventual structure solution. The inset shows the optical photograph of the first pepsin crystals exposed by Bernal and Crowfoot. Crystals image courtesy of G. Ferry (Oxford, UK) and Prof. Judith A.K. Howard (University of Durham, UK).

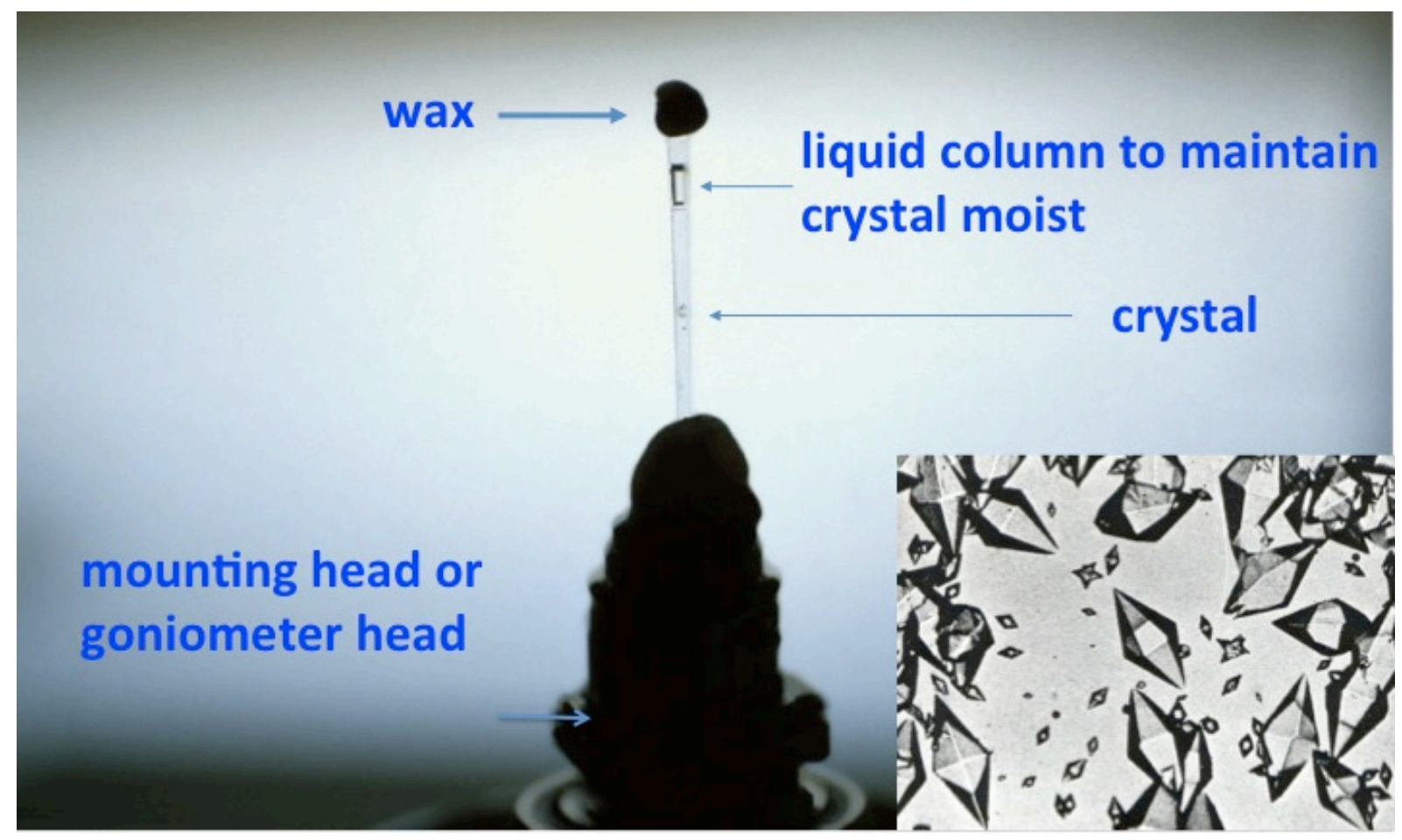

Also of great importance, although less known, is the publication in Science of W.M. Stanley (1904-1971) describing the isolation, purification and 'crystallization' of the first virus (the plant virus Tobacco Mosaic Virus, TMV) in 1935 (Stanley, 1935). The implications of this scientific event had an electrifying effect on the community of scientists devoted to understanding the phenomena of life in physico-chemical terms ${ }^{4}$. The work was technically flawed in two critical points but nonetheless, was significant in justifying the use of physical and chemical tools and methods to study biological macromolecules. The significance and limitations of this seminal paper have been discussed by Lily E. Kay (Kay, 1986) and I will briefly review two critical points.

Firstly, although the sample was considered to be pure protein and was so presented in the title of the publication, the sample of the virus purified from tobacco plant extracts had a significant amount of nucleic acid ( $6 \%$ ) (as it should!), a point that Stanley did not adequately recognize. We now know that in- fectious virus samples must contain the DNA/RNA encoding the genetic material of the virus and that the protein shell only coats the DNA.

Secondly, although heralded as a true crystal by Stanley in his publication, the biochemical group at Cambridge, including N. Pirie, F. Bawden and others, soon reproduced the results, and supported with the crystallographic expertise of J.D. Bernal they soon established that the 'crystals' were only sheaves of TMV virus fibers, roughly aligned along the axis of the long rods that constituted the TMV virus ${ }^{5}$. Nonetheless, truly ordered crystals of Tomato Bushy Stunt Virus (TBSV), Turnip Yellow Mottle Virus (TYMV) and others were soon grown and characterized as such, providing the foundation for virus crystallography ${ }^{6}$.

Much more focused on my future career plans, I came into intellectual contact with W.M. Stanley and his work by accident. He visited Salamanca and presented a seminar in 1971, invited by Prof. J. R. Villanueva who at the time was a recently appointed 
professor of Microbiology at the Faculty of Sciences. The lecture was quite interesting but unfortunately, Prof. W. M. Stanley died unexpectedly in Salamanca that very same night. The seed had already been planted. By this time, I had already decided to pursue studies of Biology, or better 'Biophysics' on my own. How did that happen?

\section{STRUCTURE OF DNA AND THE UNVEILING OF THE GENETIC CODE}

All through my studies of Physics and particularly in the last three years or so, I had expanded my intellectual landscape by reading and studying biology on my own. Somehow, the study of biology attracted me and I should mention that even though it was only a minor subject in the first year, I obtained my best grade.
I was interested in biology. The biology professor had mentioned the unique properties of enzymes in various lectures. They were able to catalyze complex chemical reactions at speeds orders of magnitude faster than under standard conditions on a test tube. He had also questioned about the structure of DNA in the final exam by asking to write complementary sequences of bases, but it was not clear to me what it all meant (see Figure 4). Nonetheless, I was inclined to follow these ideas and read more about them.

In our student flat, my colleagues and I set up a blackboard to facilitate the discussion of our conversations and also to provide a place to study. I remember very clearly writing down things about the structure of DNA and also discussing the content of some of the articles appearing then in the English Edition of

Figure 4. DNA-model. A replica of the B-DNA model built by Watson and Crick at the Cavendish Laboratory in Cambridge, based on the diffraction patterns of moist fibers obtained by R.E. Franklin. The crucial element of the two chains running in opposite directions is apparent in this view as well as the hydrogen-bond base pairing of the bases at the center. (Author's personal collection). Insert: Legend of the model exhibited in a Cambridge, UK, museum.

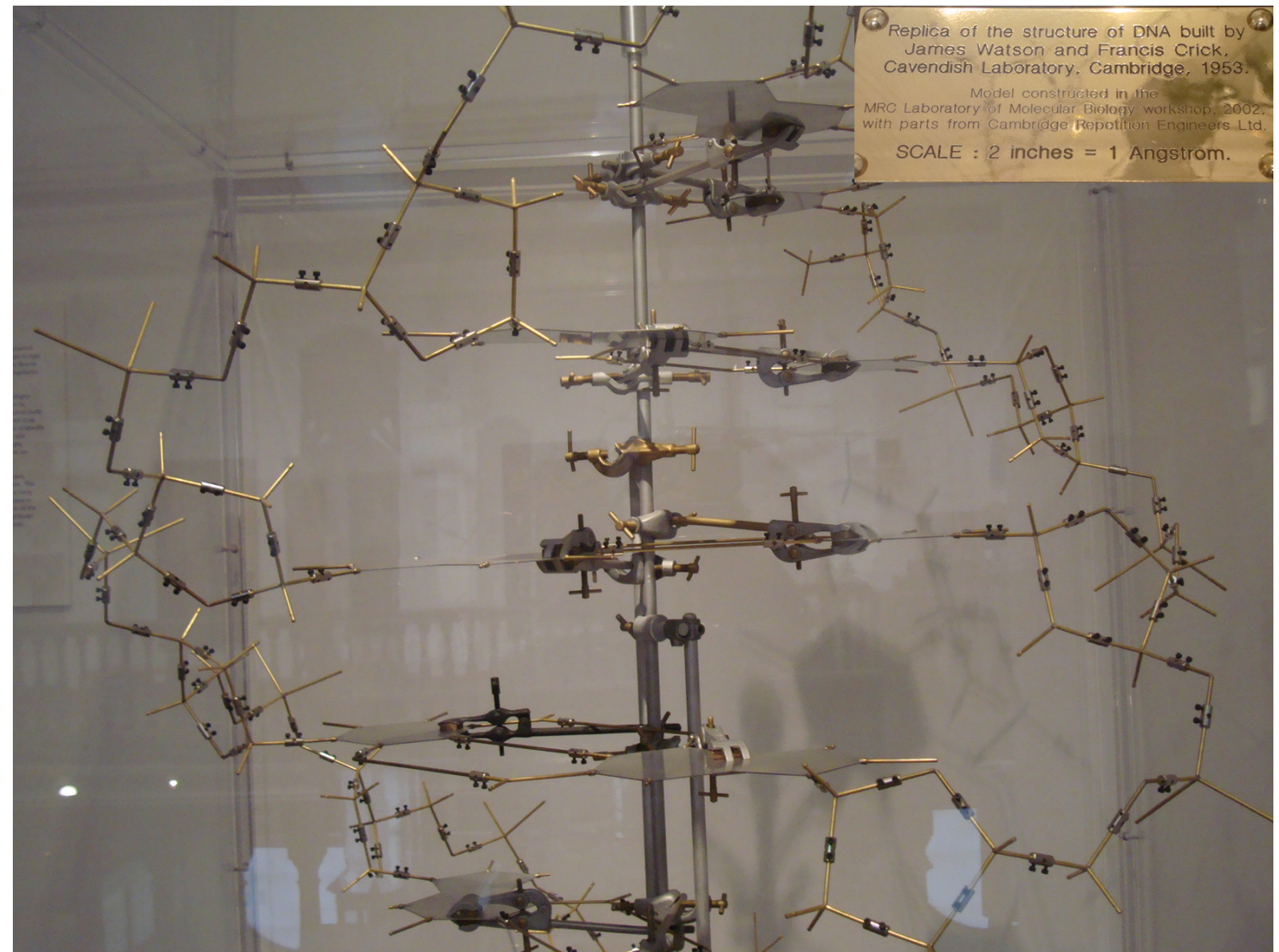


the Scientific American. I have memories of writing on the blackboard the names and initials of the purinepyrimidine bases forming the core of the DNA structure and also, the 'codons' of the amino acids as they were unveiled by the work of Ochoa, Nirenberg and Crick, although at that time even the names of Watson and Crick were not household characters; never heard of Rosalind Franklin. Soon the words 'The Complete Genetic Code' with the conventional three-entry cipher table with the equivalence between triplets and amino acids, made its way into the blackboard of the student flat in Valladolid. There was interest and attraction. In retrospect, these sessions with my colleagues (whom I am not certain they could follow or even had interest in my ruminations) could represent examples of the notion that Francis Crick has referred to as the 'gossip test' theory of scientific interest (Ridley, 2006) ${ }^{7}$. He refers to his observation that in his personal experience, whatever you like to 'gossip about' (even if you don't know much) is probably what interests you and it is what you should consider following professionally. I certainly did not know this at the time but it has proven to be true with me also.

\section{FIRST PROTEIN STRUCTURES}

The decision had been made then: to pursue studies of modern biology, somehow; to apply the physics that I had learned to some biological phenomena or some aspect of modern biology. However, this was much easier to say than to implement. How? Where?

These were the late nineteen-sixties and the structures of the first two proteins, hemoglobin and myoglobin, had already been published; significant progress was already been made. I also remember reading about the structure of lysozyme in Scientific American with the superb illustrations of I. Geiss (Phillips, 1966). In those illustrations, the structures of proteins appeared to be an intricate 'atomic forest' of lines and tunnels where mysterious chemistry would take place.

Unfortunately, the curricula of university courses and studies in Spain were rather rigid and I could not pursue this work in Valladolid because the Faculty of Sciences did not offer degrees in Biology. If I wanted to study biology, I may have to start from scratch and get an independent degree in Biology at a different city; Salamanca, approximately eighty miles away was a possibility. There was also the need to find an independent mean of financial support. I had been lucky to be supported by a scholarship for the last four years of my undergraduate studies and I certainly could not expect any support form my parents.
I do remember very vividly that in one of the hallways of the University of Valladolid there were some very plain notices on the walls announcing 'Fulbright Scholarships'. They were very brief, barely two-thirds of a page, double-spaced typed in English, announcing scholarships to pursue graduate studies in the U.S.A. This was a thunderbolt. Could it be possible?

There was also a call for applications for scholarships to do graduate work. These were more common and it was reasonable for a student to apply for such scholarships to pursue a graduate program in your 'major' (Physics in my case) to complete a dissertation in one of the physics departments and then possibly apply for a tenured position within the Spanish University system. I was not inclined to follow this route. If I applied for a graduate scholarship, it should be to 'apply physics to biology' in one department of the University Salamanca, where I could study and follow biological research. Indeed, I sent the application to study Biochemistry, Genetics and do graduate work in the Department of Genetics in Salamanca, under the generous mentorship of Prof. Fernando Galán. I do say generous because Prof. Galán, one of the recognized figures in Genetics in Spain, accepted and supported my application with only a vague notion as to what I could do with my physics background.

Nonetheless, with my better than average grades I was awarded the 'hybrid' graduate scholarship to pursue studies of Biology in Salamanca for the purpose of applying my physics background knowledge to some speculative work in genetics. My main focus was to audit courses of Biochemistry, Genetics and Microbiology since I could not register for regular courses in the Biology curriculum. Importantly, during this time I attended seminars, lectures, conferences (i.e. W.M. Stanley plenary conference above) and certainly applied for the Fulbright Scholarship. I soon realized that the academic environment in Salamanca could only offer me limited opportunities to do solid graduate work in Biology.

Macromolecular crystallography was certainly not in my immediate plans. As part of the proposal and application for the Fulbright Scholarship, I had to prepare a curriculum and possibly suggest a project. The best that I could do at the time was paraphrasing the chapters of the book Molecular Biophysics (Setlow and Pollard, 1962) that was a solid introduction to biophysics. I did purchase the book and read it (even studied it) with tremendous dedication. There were chapters on protein crystallography, nucleic acids structure and so many other interesting things. There was a whole curriculum devoted to physics and biology; I found this very encouraging. I was not dreaming. 


\section{COMING OF AGE OF PROTEIN CRYSTALLOGRAPHY}

Scientific and personal developments happened very fast then. Having found a focus to my scientific career and research and having fallen in love with Victoria, a dearest young woman willing to share my dreams, we married in December 1970 in the small town of Milagros (province of Burgos), where my father was born. We lived briefly in Valladolid and soon moved to Salamanca where I should continue my graduate research in the Faculty of Biological Sciences. I prepared intently for the different stages of the Fulbright scholarship application.

The formal application, exams (TOEFL, GRE) interviews and other requirements for the Fulbright scholarship were duly completed. There was quite a bit of excitement and anxiety as the time passed by and I did not receive any communication from the committee. Soon 1970 continued on to 1971 and although the work and study continued in Salamanca, I was quite unsatisfied.

In the meantime, in 1971 there was a momentous meeting in Cold Spring Harbor Laboratories in the U.S.A. where macromolecular crystallographers (i.e. crystallographers of proteins and viruses) came together to celebrate the 'coming of age of protein crystallography'.

The field had matured from the timid beginnings of hemoglobin and myoglobin, and was ready present to the world that the dream of a very limited number of visionaries was now a reality. The proceedings of the symposium published in 1972 proved beyond reasonable doubt that the protein crystallography had reached a healthy adulthood (Watson, 1971) ${ }^{8}$.

The closing address by D.C. Phillips summarized the origins, present status and future of the field. The early diffraction patterns of protein crystals by Bernal and Crowfoot lead the way to the initial successes of the Multiple Isomorphous Replacement Method (MIR) in the structures of the two initial globins. The triumphant development and extension of the MIR method gave the structures of lysozyme, ribonuclease, carboxypeptidase-A, and subtilisin at high resolution between 1960 to around 1968 .

The results presented at the meeting were considered to be the proof of a period of consolidation, given the number of novel structures presented and also the biochemical implications of the results for biochemistry and molecular biology. The initial structures solved in the pioneering period were relatively small proteins, monomeric and typically extracellular, many of them catalyzing hydrolytic processes of large polymeric substrates. The results reported at the Cold Spring Harbor meeting expanded these achievements to include the structures of much larger intracellular enzymes, among them the tetrameric lactate dehydrogenase. There were reports of the novel structures of carbonic anhydrase, reduced cytochrome $c$, cytochrome $b_{5}$, carp muscle albumin, high potential iron protein, trypsin and trypsin-inhibitor complexes. There was also indication of the imminent structures of other important proteins such as Concanavalin A, Flavodoxin, malate dehydrogenase and triose phosphate isomerase among others.

In addition, there were communications describing the morphology of virus by Electron Microscopy and the first solid results of the structure of fibrous (TMV) and icosahedral (TBSV) viruses using $\mathrm{X}$-ray diffraction methodology (Watson, 1971). The field of macromolecular crystallography was definitively established and would endure.

Another important event took place at that meeting although only in the background, the birth of the Protein Data Bank. At this meeting the very same crystallographers that were producing the structures and the results, realized the importance of having a public depository of structures for the benefit of the crystallography community itself and of the biomedical and biological communities at large. The pioneering efforts of Walter Hamilton, Helen Berman, Tom Koeztle and others gave fruit and today the world wide PDB (wwPDB) is an immensely valuable resource for the biomedical community worldwide containing over 100,000 structures (Abad-Zapatero, 2012).

A telegram from the Fulbright Commission received in late June 1972 alerted me that I had been awarded the scholarship to pursue studies of Biophysics at the University of Texas at Austin and that I needed to contact the office for the logistic arrangements. The miracle had happened! We packed our belongings and shipped them to the residence of my parents in law in Irun (Basque country) and prepared to be in Austin in the fall of 1972. I had not been exposed yet to the current status of protein crystallography. In fact, I did not know that I would be following that path. The field was waiting for me upon my arrival to Austin, Texas, in September of 1972. 


\section{MOLECULAR REPLACEMENT, NUCLEOTIDE BINDING FOLD AND SUPER-SECONDARY STRUCTURAL ELEMENTS}

The efficiency and organization of an American University were the first discoveries that I encountered upon my arrival to the capital of Texas, a modest sized city in the middle of the Lone Star State. I had never heard of this city before as opposed to Houston or Dallas, the latter of JFK infamous fame. I soon enrolled in several courses that my advisor Dr. J. L. Fox recommended, among them computer science and programming, subjects of which (inexplicable to him!), I did not know anything. I was indeed very pleased that I could take classes in subject matters where my background was weak. I always found to be a limitation of the doctoral studies in Spain that you actually could not do that. The graduate classes were always a formality and you hardly ever learn anything new or valuable for your research. You were supposed to know everything and just had to start right away with your thesis project.

After a few semesters filling holes in my knowledge of biology and physical chemistry and taking a course in crystallography, I found a protein in the laboratory of Prof. Fox that I decided to try to crystallize on my own. This was C-Phycocyanin, (CPC) a beautiful blue colored protein extracted from the marine blue-algae Agmenellum quadruplicatum. I read a few papers on using the 'diffusion method' to grow crystals and I managed to succeed. This changed the orientation of my thesis completely and changed my career.

Down in the second floor of Patterson Laboratories a couple of young protein crystallographers were trying to start independent laboratories, Marvin L. Hackert and Jon D. Robertus. I came downstairs with my crystals and my training as a protein crystallographer began. I did not know anything about these younger faculty members. As it turns out, Robertus as a postdoct with Aaron Klug at the MRC, had solved the structure of the first transfer RNA (Yeast-Phenylalanine-t-RNA) in 1974s and Hackert had been a postdoc with Michael Rossmann working with Lactic Dehydrogenase. These two structures were major milestones in the consolidation of the field and I was indeed lucky to be able to be trained by them (see Figure 5).

It is worth taking a small detour to appreciate the significance of the structure of Lactic Dehydrogenase in the context of macromolecular structure. After the success of hemoglobin, Rossmann left Cambridge for a faculty position at Purdue University West Lafayette, Indiana. The move was probably not easy for Michael, leaving the beacon of the macromolecular crystallography field for an obscure laboratory in the American Midwest. However, he soon published a series of papers on the mathematical formulation and extension of the Molecular Replacement method and tackled the structure determination of Lactic Dehydrogenase (or Lactate Dehydrogenase, LDH), an NAD-dependent dehydrogenase that is a key enzyme of the glycolytic pathway in the living organisms. His choice was based on the fact that the enzyme had been recognized to be an oligomeric enzyme composed of four subunits and could be important to test novel methods of structure determination, beyond the well-established MIR.

One of the many pioneering contributions of Rossmann to the macromolecular crystallography was the notion that one could possibly use non-crystallographic symmetry to expedite (or even solve $a b$-initio) the structure of macromolecules. He had explored this idea already with hemoglobin in the seminal papers with David Blow and was extremely motivated to explore how far he could take it (see section on viruses). The tetrameric structure of Lactic Dehydrogenase suggested a test of his ideas.

As it turned out, the symmetry of the crystals of M4 Dog Fish LDH incorporated the 222 symmetry of the tetramer into the crystal lattice and it was not possible to continue the analysis in that direction; there was no non-crystallographic symmetry. The opportunity came later with the crystallographic studies of glyceraldehyde-3-phosphate-dehydrogenase (GPD) also solved at Purdue a few years later.

Nonetheless, the structure of LDH proved to be a treasure trove of macromolecular architecture that illuminated many aspects of structural biology (see Figure 5). In 1970, LDH was the largest structure solved by single $X$-ray diffraction using the MIR method. It revealed many details of the fold of $\alpha / \beta$ proteins, where a core of parallel beta strands was surrounded above and below by helical connections. In the eyes of Rossmann, the structure of LDH revealed a structure consisting of two separate 'domains' that could be considered structurally independent. First, there was the NAD-binding domain (i.e. nucleotide binding domain) consisting of six parallel $\beta$-strands with right-handed helical connections (see Figure 5 insert and also Figure 9) and then a substrate (or catalytic) binding domain linked together, and it was at the interface between these two domains (at the carboxy end of the parallel $\beta$-strands) that the enzymatic reaction took place (see Figure 5). This notion may appear to be obvious after more than forty years of structural biology results but it was certainly 
not accepted in the early 1970 s. To convince the skeptics, Rossmann, his colleagues and co-workers had to develop the algorithms and programs to superpose in three dimensions the structures of various proteins and domains, and provide a reliable metric ( $r m s d$ : rootmean-square-deviation in Ångstroms) between the different proteins. The technical and computational issues of 'matching pairs' and 're-assigning the equivalent residues' between the proteins in view of the presence of insertions and deletions in the polypeptide chain made things rather non-linear and unstable. It is important also to realize that all these comparison were typically done using the coordinates of the $\mathrm{C}_{\alpha}$ carbons of unrefined proteins (Rao and Rossmann, 1973) ${ }^{9}$. In the end, the evidence was overwhelming and the NAD-binding domain, Rossmann's fold as well as the existence of domains as discrete units of protein structure are nowadays commonplace (Rossmann, Moras, Olsen). It is also recognized as a powerful concept that facilitates the evolution and diversity of macromolecular structure.

Figure 5. The wire model of LDH built in the late sixties at Purdue University using 'Kendrew' atomic parts. This represents the technology of the time to build protein structures based on electron density maps drawn on glass windows using a Richard's Box (also referred to as Richard's Folly). NAD is bound in the foreground of the model (yellow yarn), corresponding to the carboxy-end of the NAD-binding domain. The device was designed by F. M. Richard of Yale University. See insert for a simplified depiction of the structure, using a rendering common in the literature in the 1980's. The $x-y$ grid used to measure the coordinates is visible on the floor of the model, where the metal rods are screwed in. The $z$ coordinate is the height from the plane of the base, measured with a plumb line. $P, Q, R$ indicate the three orthogonal 2-fold axes.Insert: Shows the Jane Richardson type of diagram of the polypeptide fold drawn by Audrey Rossmann, and the fish drawing (by the author) shows the arrangement of each monomer within the M4 LDH tetramer. The tail of the fish mimics the extension at the amino terminal end that can be seen clearly in the computer rendition in Figure 9. The spine and the dorsal fin of the fish are drawn approximately in the direction of the $\beta$-strands (Reprinted from J. Mol. Biology. Copyright J. Mol. Biology (Abad-Zapatero et al., 1987).

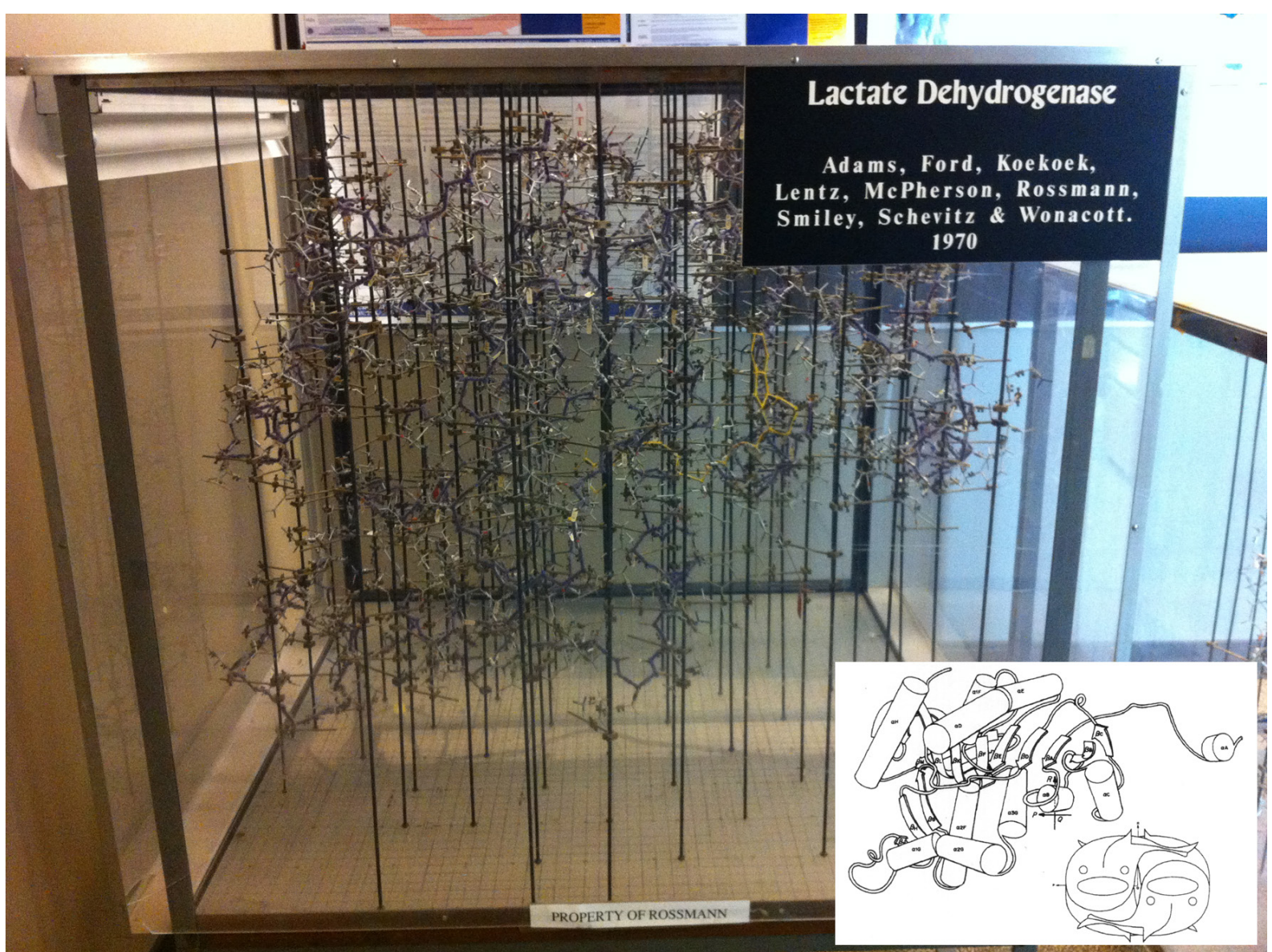




\section{LEARNING A PROFESSION: THE NUTS AND BOLTS OF PROTEIN CRYSTALLOGRAPHY}

I have written already of the excitement of these years in my modest opus Crystals and Life: A Personal Journey (Abad-Zapatero, 2002a) ${ }^{10}$. I will be studying beautiful blue crystals of CPC and later of the red protein B-phycoerythrin (BPE) from Porphiridum cruentum. I always found intriguing and fitting that with my training as a physicist I stumbled upon two proteins whose function was to trap light quanta to be transferred to the reaction centers for photosynthesis. The richness of the biological world provided an endless supply of intriguing problems for enzymologists, biochemists and physicists; my dream had been realized. I was learning a profession in a line of research where I could use my mathematical and physical training to solve interesting biological problems.

Crystals were grown and their symmetry analyzed with precession photographs (see Figure 6). The symmetry of the crystals of these two proteins was quite complex (trigonal space groups) with cell constants rather large $(a=b=187 \AA, c=60 \AA, P 321)$ compared to the structures previously solved. This was a challenge for what the technology and methods of the time could handle. Only in the later years of research the data collection by oscillation photography, with the availability of oscillation cameras (referred to as Arndt-Wonacott cameras and manufactured by Enraf-Nonius and others) permitted an efficient method of data collection.

The laboratory of Rossmann had already paved the way in developing software to process data using the oscillation method facilitating the data collection and processing of screenless oscillation photography enormously. I was lucky to learn how to collect the crystallographic data with such a method and soon thereafter to process with the oscillation programs coming from Michael's lab. Two key concepts were implemented in the Purdue package that made the processing of oscillation data more robust and reliable (Rossmann, 1979) ${ }^{11}$. First, the 'convolution' or multiplication in a volume of reciprocal space of the observed structure factors (i.e. $\mathrm{F}_{0}$ ) with the estimated ( $F_{e^{\prime}}$ based on the parameters of the experiment) to maximize the overlap and properly assess the rotation angle. Second, the use of profile fitting to estimate the intensity of the observations, using the optical density values of the scanned films.

The two structural problems that I had chosen for my Ph.D. research were too difficult to solve with the technology of the time. In a way, is like what hap-
Figure 6 (6a and $6 \mathrm{~b})$. Example of the crystallographic analysis of B-Phycoerythrin, a phycobiliprotein from red algae that was the subject of the author's Ph.D. dissertation. These images reflect the technology of the time, using predominantly precession photographs ( $A$, $B, C$ and D) and the early oscillation patterns obtained using oscillation cameras installed in a rotating anode $\mathrm{X}$-ray generator (Figure 6b).

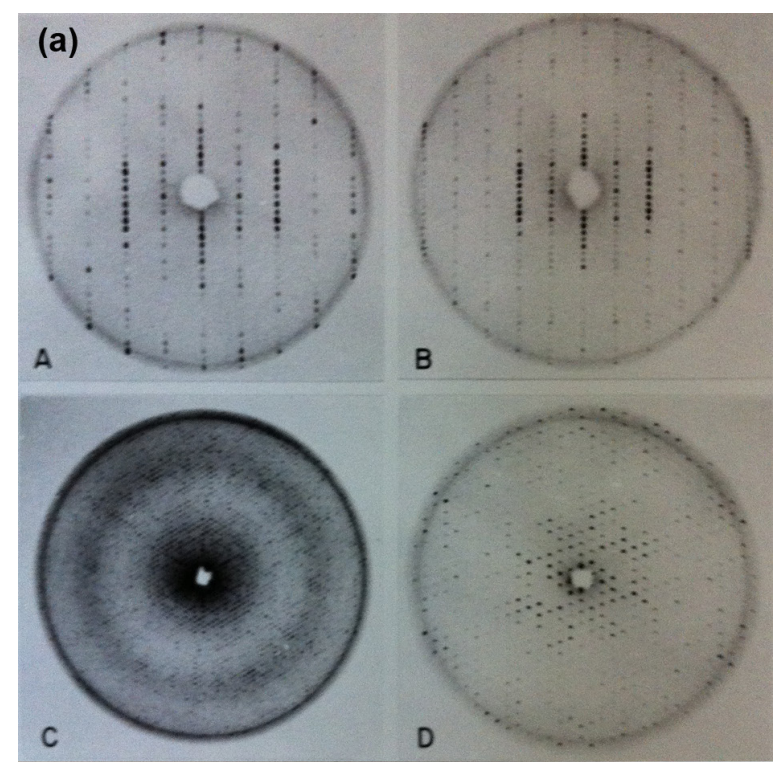

(b)

pened to Bernal and Crowfoot in analyzing the first protein crystals of pepsin, where the space groups was hexagonal with a very long screw axis along the main symmetry axis, resulting in a cell dimension along c larger than $200 \AA$. Of course, at the time of their pioneering studies of it was impossible to solve the phase problem. Since then, the MIR method had been established and the methods of data collection and processing had improved dramatically but in the environment of the early laboratory of my dissertation supervisor (Marv Hackert), we could not solve the 
problem. I had fulfilled my dream of doing biophysics, crystallography, structure biology but I had not succeeded in solving the structure of a protein yet. There was still much to be learned.

\section{FIRST VIRUS STRUCTURES: JELLY-ROLLS AND OTHER SURPRISES}

In the late 1970's, protein crystallography was still a research field that required knowledge and expertise in many areas and whose methods were still in full development and growth. There were the biochemical skills to grow crystals, typically extracted from the natural sources. Knowledge of instrumentation (X-ray generators, X-ray optics) and indeed computer programing, since the software tools for data processing, scaling and Fourier calculations were still the creation of different laboratories. Although I had learned most of those techniques in Austin, I needed further postdoctoral research experiences to feel confident enough to set my own lab in a few years, possibly in Spain.

I attended the West Coast Protein Crystallography Workshop in Asilomar (California) in the spring of 1978 and was impressed by the early results on the structure of Southern Bean Mosaic Virus (SBMV) that Michael Rossmann presented. I did talk to him at the end of his lecture and, right on the spot, offered me a postdoc position. I told him about my US-Visa issues, since my six years J-1 visa would expire at the end 1978. He told me not to be concerned, because Purdue University could sponsor another J-1 visa as a postdoctoral associate.

I remember flying back to Austin completely elated as to the new turn of events, with the music of Mozart (the famous serenade Eine kleine Nachtmusik, no. 13 in G major K. 525) in the headphones. The next few months were of intense activity and during the month of August I wrote my first full draft of the dissertation. I should add as a note that prompted by a computer science colleague of mine, I typed my entire dissertation in one of the early computer editors and I printed the various versions and high quality copies with one of those 'flywheels' in the computer printer. Everything was soon ready and at the end of October, I defended my dissertation at the University of Texas. The day coincided with my father's birthday and so I did send him a telegram with the news. In the later visits to my parents, I saw the telegram framed in a prominent place in the house.

Victoria and I had been six years without seeing our parents. So early in December, we flew back to Spain with the plan of visiting several crystallography laboratories in Europe where there was also a flourish of activity and excitement in the field. The laboratories of Jan Drenth (Groningen, Netherlands), Robert Huber (in Martinsried, Munich, Germany), Ken Holmes (Heidelberg, Germany) and Jan Jansonius and Rogert Burnett in Basel had already made significant discoveries in protein crystallography. We stayed for a few days with our respective families for the Christmas holidays and returned to the USA in January 1979.

The years at Purdue in the laboratory of Rossmann were extraordinary. We were a dedicated group of postdocs working to extend the methods of protein crystallography to determine the structure of the first virus. There had been several generations of researchers before me working on the different aspects of the project: Jack Johnson, Toshio Akimoto, Sherin Abdel-Meguid, Andrew Leslie, Ivan Rayment, Dietrich Suck, Ira Smiley all under the leadership of Michael. The challenges were many and varied and I have written about them before in Crystals and Life (Abad-Zapatero, 2002a) and also in a more extensive account with the full text of 'The Ballad of the $2.8 \AA$ Structure of SBMV' (Abad-Zapatero, 2013a) ${ }^{12}$. A brief summary will put the work in the context of the development of macromolecular crystallography.

Virus production in large quantities required culturing the plants in greenhouses, infect them and harvest the leaves. The virus was extracted and purified from the ground leaves and crystallized. Plant viruses typically yield several grams of pure virus for each batch. High-resolution diffracting crystals had been already obtained from TBSV and the group of Steve Harrison at Harvard was working in them and was clearly ahead. There were also the crystals of Satellite Tobacco Necrosis Virus (STNV) in the group of Bror Stranberg in Sweden, where Michael had spent a sabbatical after the structure of LDH.

After his return, he had decided to focus on a virus project to explore his dream of solving the structure of a virus using the non-crystallographic symmetry. Jack Johnson developed the protocols to grow the crystals of Southern Bean Mosaic Virus that turned out to be R32 with cell dimensions $(a=b=334.30 \AA$, $c=757.50 \AA$, H32 cell) and diffracted to $2.8 \AA$ resolution.

The size of the unit cell should give an idea of the staggering amount of good quality data that had to be collected, processed, scaled and carefully analyzed to apply the method of MIR to determine the structure. The first two globin structures that were solved had cell 
dimensions an order of magnitude smaller. Thus the number of reflections was approximately a thousandfold larger for the virus project. The methods and algorithms developed using the oscillation photography were critical and using nickel-filtered focusing mirrors to reduce the cross-firing of the X-ray beam produced by conventional rotating anode generators (synchrotron radiation was still not available) was critical.

More importantly, the algorithms and programs to allow the implementation of electron density averaging in maps containing such an enormous number of grid points were not available. The computer memory, disk storage and other hardware of current installations were not capable of handling such a task. The group of Harrison at Harvard was able to do the calculations with algorithms and programs developed by Gerard Bricogne at the CECAM workshop in Paris early in 1978. A similar algorithm (double-sorting) had been developed and programmed by Jack Johnson at Purdue University and would still take about two weeks per electron density average cycle. Not surprisingly, the structure of TBSV was published first in 1978. The tracing of the chain, still without the amino acid sequence, revealed a 'jelly-roll' or $\beta$-barrel. This description refers to a series of eight anti-parallel $\beta$-strands, with some extensions and protrusions on the connecting loops.
The image and morphology of TBSV and SBMV based on the previous electron microscopy studies appeared to be dramatically different. Yet, the striking surprise of the structure of determination of the second one by the Purdue group in 1980 was that the protein folds were essentially identical (see Figure 7) (Abad-Zapatero et al., 1980). Both contained the 'jelly-roll' topology and this result was certainly unexpected; the strikingly different external appearance of two viruses was due to the presence of two 'jelly-roll' domains in TBSV, one of them protruding ( $\mathrm{P}$-domain) from the icosahedral surface that was formed by the shell domain (Sdomain). In scientific research, typically one strives to be the first one to unveil certain discoveries, however, often the results and implications of being second can be far more spectacular. In a way, the story of the common folds of myoglobin and hemoglobin, the first proteins determined by crystallography, repeated itself with the two structures of the first two viruses determined at atomic resolution. These finding again had implications for the evolution of virus structure, given the constraints of the icosahedral shell required to enclosed the genetic information, encoded in these early virus in a single strand of RNA.

Figure 7. M.G. Rossmann's research group at Purdue University circa 1980 when the structure of SBMV was first established by X-ray diffraction methods. There were several protein projects besides the virus. Michael is wearing the hardhat that he used to build the SBMV model with the author who is to his right.

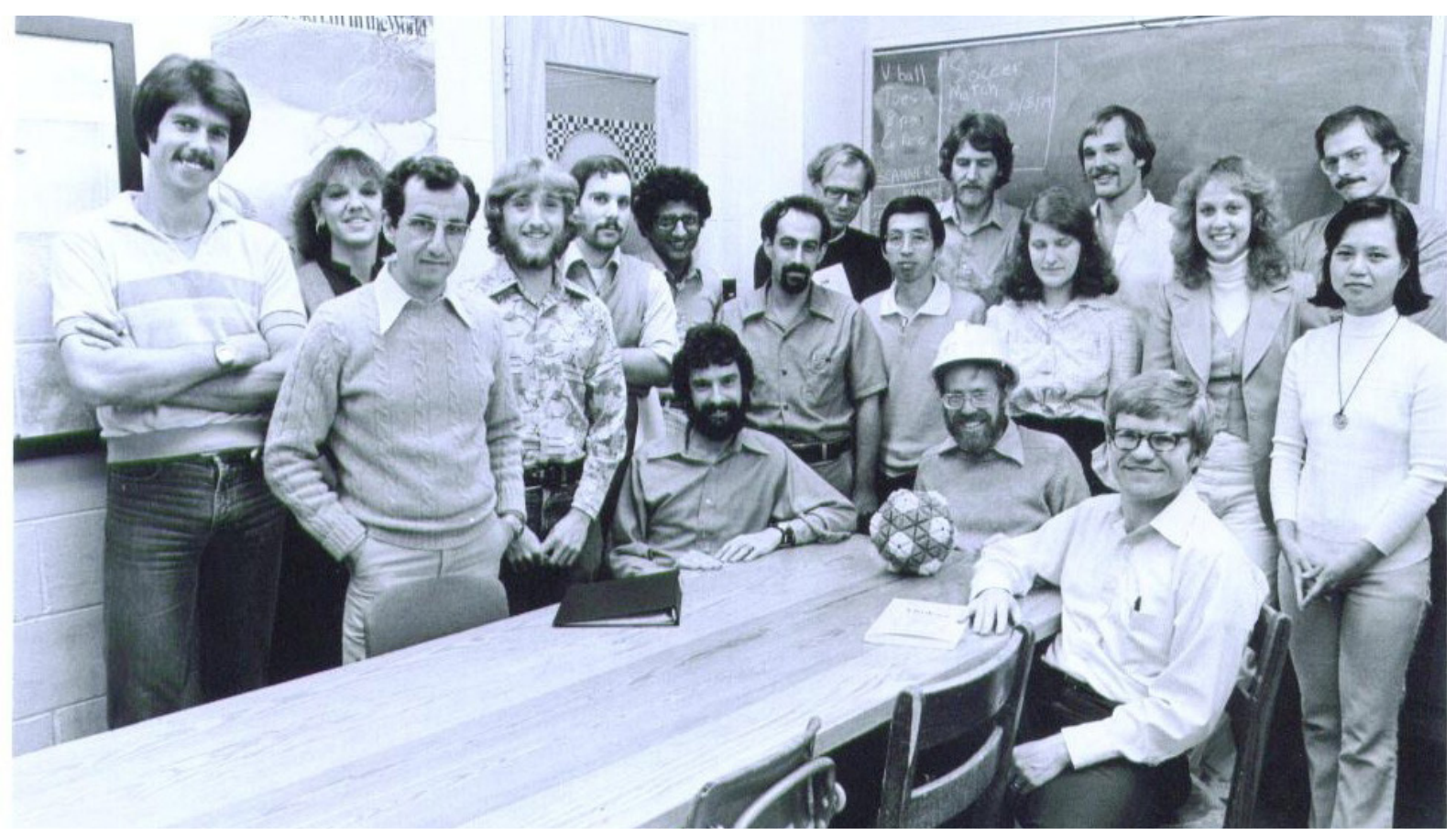


I was extremely lucky to arrive to the Purdue group at the time when the effort of so many colleagues and dedicated co-workers was about to yield the ultimate reward of the successful structure determination. I processed data, refined the position of various heavy atoms derivatives, did the electron density averaging and was fortunate enough to build the structural model with Kendrew metal parts in a Richard's Box that was the technology used at the time (see the model of LDH in Figure 5). The model grew up of metal parts in a special room with the electron density map sections drawn in glass windows, illuminated with a movable light that lightened the corresponding parts of the atomic model and reflected them on a half-silvered mirror. I measured the coordinates of the atoms on an $x-y$ horizontal grid at the base of the model and the $z$-coordinate with a plumb line ${ }^{12}$. The structures of the three different polypeptide chains $A$, $B, C$ were obtained similarly and deposited in the PDB, written on a computer eight-track magnetic tape. A partially refined structure was deposited a few years later resulting from the efforts of Abelardo Silva and Rossmann. During these early years at Purdue, I met Ignacio Fita, a young postdoc from the laboratory of Joan Subirana in Barcelona, who together with Miquel Coll have played a very important role in establishing macromolecular crystallography in Catalunya and Spain. Our lasting friendship dates from those years in Michael's lab.

\section{REFINEMENT OF PROTEIN STRUCTURES: COMPU- TING AND COMPUTER GRAPHICS}

There was tremendous excitement in the lab after the structure of SBMV. Michael had already begun to envision another frontier in macromolecular crystallography: solving the structure of the first animal virus; and chose none other than the virus of the common cold (human Rhinovirus, HRV14) (see Figure 8). New people came into the lab that will play a critical role in the project (see below). I decided to take another challenge in the macromolecular crystallography of the time: crystallographic refinement of large proteins.

The problem was not trivial and can be expressed in rather simple terms. In a typical protein structure, the atomic model may consist of two to several thousands of atoms (myoglobin 2,500). Placing those atoms in space requires at least three coordinates $(x, y, z)$ and an additional variable ( $\mathrm{B}$, temperature factor) to give a sense of the thermal vibration of the atoms in the crystal. This implies that establishing the three-di-
Figure 8. External view of the structures of SBMV and HRV14 (left and right, respectively). Although very different in external appearances under the electron microscope, the polypeptide fold of the two viruses and many others is based on the 'jelly-roll' structure, first observed by Steve Harrison and colleagues in TBSV. The orientation is approximately the same with the symmetry elements of the icosahedral asymmetric unit marked, showing a small protrusion in SBMV at the 5-fold (red). HRV14 image courtesy of M. G. Rossmann.

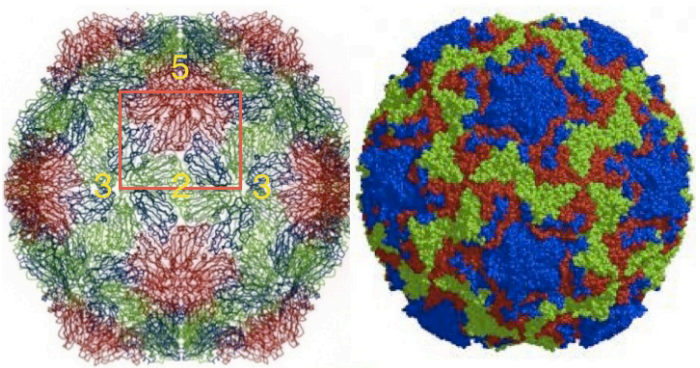

mensional structure of a macromolecule with reasonable accuracy requires at least four times the number of atoms (4N) parameters; typically, eight to ten thousand numerical parameters and normally more than that. Depending upon the diffraction quality of the crystals, the number of crystallographic observations $\left(F_{\text {obs }}\right)$ can range from twenty to thirty thousand. From the purely mathematical standpoint of least-squares refinement, the ratio of the number of observations to variables (parameters) is not favorable or even adequate. Early refinement programs pioneered by Carl Brändén to tackle the problem of hemoglobin failed miserably. There was a need to refine large protein structures but there were very few computational tools available.

There was another component to the difficulty of refining protein structures related to the way in which the original models were built. The coordinates of the polypeptide chains measured using the mechanical models were rather crude, and it was practically impossible to 'refine' them by adjusting the mechanical models. A more convenient and precise method to correct the model structures was needed. This issue brings to the forum another critical element of the technology required and developed along with macromolecular crystallography: computer technology in hardware and software. For the refinement, the computer needs were more related to computer graphics 
than software. The pioneer work of Robert Landgridge and coworkers in the computer graphics labs, first at Princeton and later in California, as well as Edgard Meyers (Texas A \& M University) and others paved the way to the computer graphics hardware and software that eventually made protein refinement and practical endeavor. The significance of this achievement was revealed in the cover of Science in February 1981, with their representation of the structure of B-DNA along the helix axis, mimicking the Rose Window of the Gothic Cathedrals (Abad-Zapatero, 2014).

The icon of this technology for protein crystallography was FRODO, the computer program that permitted fitting, building and refining the fit of the polypeptide chain to the electron density maps at the touch of an electronic pen (see Figure 9).

Figure 9. The revolutionary layout of the computer graphics screen in the early versions of FRODO (1980s). The options are presented on a menu on the right side of the screen and a cursor pen on a tablet (highlighted cross) was used to select them. The image corresponds to the tracing of the refined LDH structure (see Figure 7 ), with certain residues and a sulfate ion (center) highlighted in thick lines. Refined coordinates could be saved with the stroke of a pen.

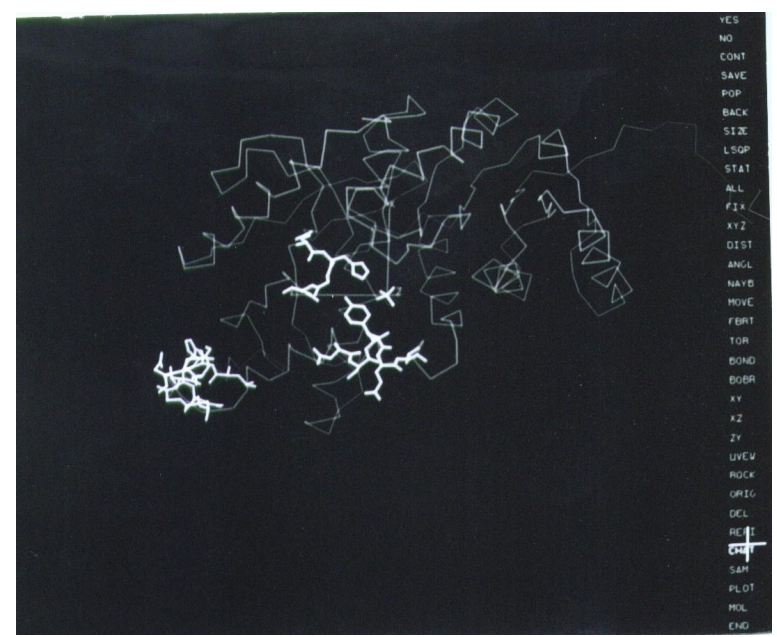

The program was developed by T.A. Jones while at the laboratory of Robert Huber in Martinsried, Germany and began to be available to the community in the late 1970s (Jones, 1978). Because of the result of a collaboration between Rossmann's lab, Alwyn Jones (Uppsala) and Joel Sussman of the Weizman institute in Rehovot, Israel, I was going to concentrate on the refinement of $\mathrm{LDH}$ using the recently established FRODO program in Uppsala, driven by an Evans \& Shuterland computer graphics and the refinement program CORELS developed by Sussman. The program CORELS was ingenious in that it had managed to reduced the number of variables to be refined by treating the individual amino acid residues with the standard geometries as rigid body ( 6 variables per residue) and then connect the groups by chemical restraints. It was a very promising approach.

In the summer of 1981, with Victoria pregnant with our first child, I left Purdue for Uppsala with a model of LDH with an R-factor of approximately 0.42 since the structure had not been 'touched' since 1970. I was going to use FRODO in Uppsala to rebuild the model with the computer graphics and then will continue on to Rehovot, Israel to do the computational refinement with CORELS. After several cycles of refinement and graphics rebuilding, a few months later, I returned to Purdue with a refined model with much better stereo-chemical parameters and a crystallographic R-factor of 0.24 . What appeared to be an insurmountable problem was on its way to a successful solution. Soon thereafter, our first child, Inés, was born giving us immense joy.

A few more months of additional refinement using the latest refinement program (PROLSQ) using full chemical restrains by Hendrickson and Konnert and the Purdue implementation of FRODO, completed the process and the detailed and elegant structure of LDH could be examined and presented in all its atomic glory. Details were published in J. Mol. Biology when I had already left Purdue (Abad-Zapatero et al., 1987). A gloriously happy event of those years was the birth of our second child Pablo on January 1, 1984. After the passing of my father in 1983 and various visa problems to achieve emigrant status in the USA, PabIo's birth was indeed a good omen for the future ${ }^{13}$.

\section{FROM VIRUS STRUCTURES TO RIBOSOMES}

After the structure of first small icosahedral, RNAcontaining virus like SBMV and TBSV, the next frontier of structural biology was the mapping of the structure of animal viruses. This presented new challenges in terms of virus production, since they had to be produced by human cells and the yields were several orders of magnitude smaller (milligrams) than plant virus. John Erickson came to Michael's lab in the final years of the SBMV work and was soon on the trail of obtaining the first crystals of human rhinovirus serotype 14 (HRN14). He succeeded soon thereafter and 
this put Michael into a sound path to obtain the first structure a human picornavirus. The name derive from 'small' (pico), RNA containing virus and they constitute one of the oldest and best characterized animal viruses, that includes the polio and human common cold, as the closest relatives within the class.

Naturally, there were technical problems that again pushed the frontiers of virus-protein crystallography to new levels. The cubic crystals $\left(a=445.1 \AA\right.$, P $\left.2{ }_{1} 3\right)$ diffracted to $3 \AA$ resolution but were extremely sensitive to radiation damage and diffracted only weakly when compared to the crystals of SBMV. These issues resulted in the introduction of two new elements in the field: i) use of the first synchrotron radiation sources (the Cornell CHESS ring was found to be the most convenient at the time); and ii) development of strategies for rapid data collection whereby two 'still' photos were taken and used to find the setting parameters of the crystal, after the collection the oscillation data from each crystal. Rossmann referred to this approach as the 'American method', where the crystals were exposed ('shot') first and the data processing was done later, typically in the home laboratories ${ }^{14}$.

With amazing speed, the rhinovirus team (John Erickson, Eddy Arnold, Gert Vriend, Libby Frankenberger, Roland Rueckert and others) was able to characterize two heavy atom derivatives ( $\mathrm{KAu}(\mathrm{CN})_{2}$ at different concentrations), and using the density averaging algorithms developed for SBMV produce electron density maps of excellent quality at $6 \AA$ resolution. At this point, Rossmann's dream of using non-crystallographic symmetry averaging provided the final and critical step to obtain high-resolution maps. The resolution of the maps was improved with the native data, using phaseextension and electron density averaging (20 fold) stepwise with no additional heavy atoms. The final maps were of excellent quality and the structure was solved in an amazingly short time. The final averaged map was calculated in April 1985 as I was leaving Purdue for Abbott Laboratories in the Northern suburbs of Chicago. The structure of HRN14 was published only five years after the unveiling of the SBMV 'jelly-roll' fold. Amazingly enough, the three proteins VP1, VP2 and VP3 comprising the capsid of HRN14 also shared the same fold with the major differences appearing at the loops between the main eight $\beta$-strands of the $\beta$-barrel found in TBSV and SBMV (see Figure 8). This was indeed an unexpected result that illuminated new vistas of the structural evolution of viruses. The structure of poliovirus by Jim Hogle and co-workers was published almost simultaneously, with very similar results ${ }^{15}$.
After this new milestone in structural biology, a series of novel virus structures soon followed from the Purdue Group (mengo, canine parvo and even bacteriophage fX174 all containing the conserved 'jellyroll' fold), transforming what was an uncertain multiperson, multi-year project into a feasible dissertation project for a motivated graduate student, as it happened with Mengo Virus (Luo et al., 1987).

There was another landmark that took a bit longer to achieve and that required the vision, stamina and hard work of several groups to achieve. This was the structure solution of one of the key pieces of the molecular biology puzzle, connected to the central dogma of molecular biology: DNA makes mRNA makes proteins; as envisioned by its 'Pope', Francis $\mathrm{H}$. Crick. The dogma depended heavily on the ability of 'ribosomes' to interpret, translate and connect the sequence of amino acids as presented in the mRNA. These had been characterized as aggregates of protein and nucleic acids (rRNA) with a molecular weight of approximately 2.5 Million Daltons and no symmetry; completely irregular entities.

I was fortunate enough to meet Ada Yonath during my visit to the Weizmann Institute in the summer of 1981. At that time, she had already obtained the first microcrystals of the $50 \mathrm{~S}$ ribosomal subunit (Yonath et al., 1980), and was exploring ways to improve their X-ray diffraction quality. Through the years she persistently pursued the vision of obtaining the three dimensional structure of these 'molecular machines'. Other researchers also contributed later to develop the heavy-atom clusters necessary to introduce 'heavy-atoms' in the native crystals that were required to adapt the MIR method to these nucleo-protein aggregates. At the birth of the new century, the three-dimensional structure of a ribosome was achieved using the combined techniques of protein crystallography and electron microscopy. Symbolically, the ultimate peak of macromolecular complexity had been conquered and three outstanding structural biologists (V. Ramakrisnan, T. Steiz and A. Yonath) were awarded the 2009 Nobel Prize in Chemistry for the accomplishment ${ }^{16}$.

A brief paragraph should be included here to expand briefly on the increasing role of cryo-electron microscopy (cryo-EM) and image reconstruction methods in structural biology. Even in the meeting of 1971 (CSHSQB, 1972) there were already communications by Aaron Klug (TMV), David DeRosier ( $\alpha$-Ketoglutarate Dehydrogenase Complex) and 
others describing the use of electron microscopy reconstruction of complex macromolecular particles. Those methods are now routine tools of structure biology and the PDB entries (EMPDB) include a significant portion of structures determined by cryo-EM, often combined with X-ray single crystal studies (hybrid-methods). The application of these methods to the determination of virus structures has also been exploited extensively by the Rossmann lab ${ }^{17}$ and others (i.e. J. L. Carrascosa at the CNB in Madrid) and is very important in the studies of the ribosome and virus structure and function.

\section{SORCERER'S APPRENTICE: STRUCTURE-BASED DRUG DESIGN}

From the unveiling of the structures of the first oxygen-carrying proteins (myoglobin and hemoblobin), it was evident that subsequent use this methodology to solve other biological problems at the atomic level would be of great interest to the biomedical community. However, it was striking to see the enormous practical impact that protein crystallography had soon thereafter in the pharmaceutical industry in the early 1980 s.

Once the first wave of academic positions in university laboratories was fulfilled, protein crystallography openings began to open for crystallographers to participate in the development of novel pharmaceutical entities in collaboration with medicinal chemists, computational chemists and pharmacologist in designing novel drugs using protein crystallography. The premise and the logic were very attractive. If most of our drugs act by inhibiting certain biological enzymes (targets) in the human body, the ability to crystallize those active compounds with the associated targets should allow medicinal chemists to design superior drugs by 'seeing' the interactions between the target and the ligand. Designing better compounds (drugs) should be expedited by 'rationally' designing superior compounds that will complement the active site pockets of those biologically important molecules. The presumptuous adjective of rational was later replaced by 'structure-based' but the concept was the same. The methodology should permit a faster design and synthesis of active compounds that could end up in the clinic, saving years of effort. This was the concept of Structure-Based Drug Design illustrated in Figure 10 (Abad-Zapatero et al. 1996).
Figure 10. Structure of the Candida albicans (a pathogenic fungus) protease SAP2 with an inhibitor designed by Abbott Laboratories medicinal chemists. This image represents the iconic concept of SBDD (Structure-Based Drug Design) using the computer graphics of the late 1990's. The $\beta$-strands of the protein structure are represented by arrows. This representation was made popular by the program RIBBONS that was initiated by Mike Carson, a graduate student colleague at the University of Texas at Austin. The protein fold is very similar to the digestive enzyme pepsin and blocking the active site is possible to see the inhibitor drawn with spheres. The color change ramps from red for the beginning of the chain ( $\mathrm{N}$-terminus) to blue at the end of the polypeptide (C-terminus). Created using PDB entry 1ZAP and the program CCP4MG version 2.5.2. (Abad-Zapatero et al., 1996).

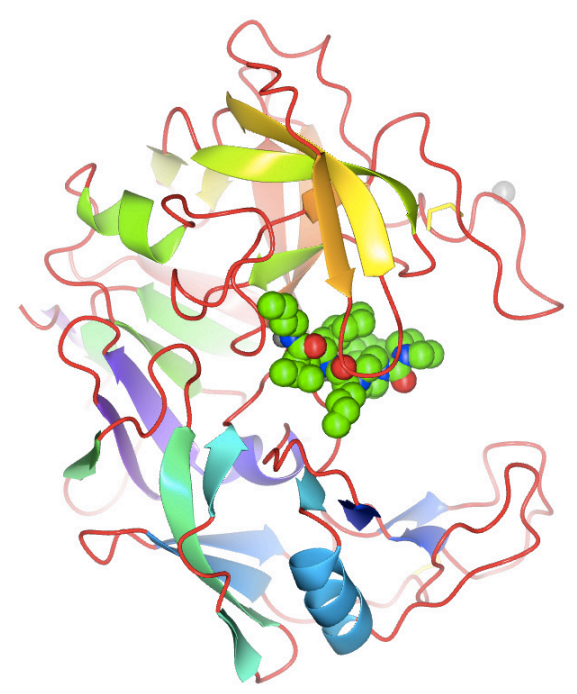

After a few failed attempts to incorporate myself into the fabric of the academic and research community in Spain, I was able to use my professional training in the pharmaceutical industry for more than twenty years. Those were years of tremendous expansion and development in macromolecular crystallography in the private sector. Our laboratory (John Erickson and I founded the lab) was integrated with medicinal chemists, computational chemists and pharmacologists to bring to the market significantly bioactive compounds. The protein crystallography laboratory at Abbott Laboratories (Abbott Park, Illinois) participated in a multitude of projects of which the most visible one was probably our participation in the development of drugs against the human immunodeficiency virus (HIV), based on the specific inhibition of the HIV 
protease, involved in cleaving the poly-protein resulting from the translation of the virus genome into its individual components and among them the protease required for infection. The methods and approaches explored and developed at Abbott and many other pharmaceutical companies (Agouron Pharmaceuticals, Merck, Pfizer and many others) are now commonplace in laboratories dedicated to drug discovery in the private and public sectors.

Many more years followed, where the pharmaceutical industry designed and built specific synchrotron beamlines as part of the IMCA consortium at the APS to cater to the needs of the private companies, and indeed expedite the access to excellent crystallographic data on target-ligand complexes to guide medicinal and computational chemists. The engineers at Abbott laboratories in collaboration with the protein crystallographers also developed the first crystal-mounting robot (i.e. ACTOR) that was the prototype of the commonly used robots now in synchrotrons all over the world (Abad-Zapatero, 2005).

However, in spite of all the ingenuity and brilliance of the researchers in the pharmaceutical industry and in academic laboratories, the challenges of developing new chemical entities are still not amenable to straightforward 'optimization' methods, as it is possible in other engineering endeavors: 'rational' (as in optimized) drug-design continues to be a challenging endeavor. The complexity of biological systems and the subtleties of biochemistry, genetics and pharmacology prevent a direct 'optimization' path. Currently, after my retirement from Abbott Laboratories, I continue to explore ways to map chemico-biological space (AtlasCBS: https://www.ebi.ac.uk/chembl/atlascbs/intro.jsp) in ways that could be relevant to the pharmaceutical industry (Cortés-Cabrera et al., 2012; Abad-Zapatero, 2013b). I will only add that since chemistry is not my strongest background, I only see myself as a 'sorcerer's apprentice', when faced with the challenges of chemistry, biology, medicine and drug design. Some of these challenges are common with the most exciting problems in structural biology (i.e. receptors, membrane proteins and others).

\section{MICRO-CRYSTALS, NANO-CRYSTALS AND BEYOND}

The research in the broad area of crystallography and the study of crystals and crystalline materials, including quasi-crystals, will continue. The most recent International Union of Crystallography Congress (IUCr2014) in Montréal featured more than hundred micro-symposia on themes related to crystallogra- phy. Probably over 2000 delegates participated in the sessions. The research related to crystallography will continue in many directions and among them macromolecular crystallographers will explore: enzymes and macromolecular machines, XFEL macromolecular crystallography, diffuse scattering and partial disorder in complex structures, molecular mechanisms of therapeutics and resistance, challenging macromolecular crystals, biological electron crystallography and many others. I would like to add a note on what I think is the most amazing frontier in the field of macromolecular crystallography that certainly could have not been envisioned when the field started.

A few years ago, the community of physicists and that built the third generation synchrotrons (ESRF, APS, Spring8 among others) began the planning and designing of the a new source of $\mathrm{X}$-rays that will surpass by several orders of magnitude the brilliance of the existing sources. Moreover, these sources will have a coherence in space and time (a measure of parallelism of the X-rays and of their synchrony in the time variable, respectively) far superior to the one existing in existing sources. According to the design specifications, these properties permit to obtain the diffraction pattern of individual macromolecules, based on the observation that it is possible to obtain a diffraction pattern with very short (femtosecond, $10^{-15}$ seconds) pulses before the sample explodes given the intense power of the incoming X-ray beam ('diffraction before explosion'). These sources are referred to as X-ray Free Electron Lasers or (X-FEL) and the first installations (LSLS) are now already in operation in Stanford (USA) and soon at DESY-PETRA III (Hamburg, Germany) and Swiss Light Source.

Large teams of researches have already managed to develop experimental layouts that permit to record the diffraction pattern of micro (or even nano) crystals being transported by the flow of liquid or gel solutions (or particle aerosols), in a direction perpendicular to the X-ray beam. In addition, the frontier of image reconstruction based on the diffraction of single molecules ('crystallography without crystals') as well as single particle tomography will continue to work on even larger macromolecular structures or even cell organelles. Landmark papers have already been published and at the Montréal Congress technical details and striking results were reported. As many speakers proclaimed during their lectures, 'The Future is Bright' for the field of macromolecular crystallography.

There is a myriad of interesting biological problems to solve using these methods and the younger 
generations of crystallographers and structural biologists jointly should prepare themselves to make use of these unique $\mathrm{X}$-ray sources to continue our search, and with our persistent curiosity and interest, further our understanding of the molecular machinery of life at the atomic level. I am still intrigued by the interplay between the conservative structures that we continue to solve by the current methods now and the dissipative structures ${ }^{18}$ that constitute the essence of the living beings; this is the frontier of my personal curiosity; where I would go if I were young again. The availability of the new X-ray sources will undoubtedly aid in exploring this domain of structural biology.

\section{REFLECTION}

After reviewing the amazing achievements of macromolecular crystallography in such a short time ( $\sim 0$ years), a reflection is probably appropriate. Protein structures are solved nowadays at an amazing speed, once the data are collected in synchrotron sources all over the world. In academic and private laboratories, biochemists, geneticist, cellular biologists and other researchers solve today the structures of their interest using the software tools developed by macromolecular crystallographers in the last decades. It would seem that:

"Protein Crystallography has become the unexpected victim of the ingenuity, inspiration and hard work of protein crystallographers themselves. Years of crystallographic and mathematical expertise are now canned in effective, rapid and user-friendly software packages, covering all the aspects of the process: from Patterson function solution and heavy atom location to phase calculation and model refinement. Rapid computers with practically unlimited disk space and memory drive all this crystallographic wizardry"

I wrote these lines more than a decade ago (AbadZapatero, 2002a) and the message is even more evident nowadays. Is macromolecular crystallography dead? In the essay, I argued that it is not dead and will never be. It is forever embedded in the fabric and texture of biochemistry, structural and molecular biology, cell biology and so many other fields. The methods are now used by prominent molecular and cell biologists, biochemists, protein and biomaterial engineers, drug designers (like I was!) and so many other biophysical and biomedical researchers. It is now underlying the fabric of all branches of scientific enquiry that have the aim of understanding life processes at the molecular and atomic level.
However, the current situation raises several questions regarding the future of the field that have been raised before but take now a more poignant perspective. Who will write the software tools for the future when the current experts are gone? Is crystallography a legitimate field of research? Is with worth teaching crystallography? What does the future hold? Some of the answers to these questions are presented in the article mentioned with the perspective of 2002. I would like to add a few additional comments.

Yes, crystallography should be taught in the science curricula related to Mathematics, Chemistry, Physics and even Biology. In a way, I think that it is as fundamental as Newtonian mechanics. However, there are two problems that complicate the teaching and the appreciation of its value among the students and the public at large.

First, the subject matter is 'multidisciplinary'. It participates from Mathematics (predominantly theory of Symmetry, Group Theory and Fourier transforms), Physics (Scattering and Diffraction Theory) and Chemistry and Biology in the interpretation of the results, for most of the applications. It just seems too much to learn to answer some specific question in a limited field of enquiry, particularly in Biology.

Secondly, to appreciate its value and interest to the student population, it has to be taught from beginning to end, meaning from crystal symmetry to the intended results in the field of interest (structural biology, drug discovery, etc.) for the student to appreciate its value. Introducing crystallography by just covering crystals and Bragg's Law, for instance, does not allow the student to grasp the full value and power of the methods. Partial measures and elementary introductions are not good enough. In my view, the programs that have been developed as 'working tools' can also serve as great teaching instruments to remove the drudgery of learning isolated facts without context. Most of us learn by doing and by working out examples. The availability of some standard datasets (i.e. native, heavy-metal substituted, known and unknown exercises; some now available from the PDB) with 'teaching scripts' to complement the lectures with practical exercises, is probably the most realistic and effective approach. If we can ignite the interest and the curiosity, the students will strive to learn more to solve their own problems and stretch and extend the limits of the field leaving space to human ingenuity and creativity. In my view, this approach combined with the availability of a limited number of 'experts' for consultation will suffice to maintain the vitality of 
the field. New experts will mature mentored by the current ones, as the new problems require the development of new tools for the community.

\section{PERSPECTIVE}

By retelling the story of the origins and development of macromolecular crystallography from a personal perspective I hope to reach the younger generations of researchers in general and Spanish scientists in particular. It is indeed true that the scientific, cultural and societal atmosphere of Spain has changed dramatically in the last fifty years. Spain is now a full member of the European Union and the issues of isolation and limited resources that were presented in my narrative may not resonate with the younger people of today and are indeed not true anymore. However, there are two elements in my journey that can certainly relate to the situation of the younger generations of scientists.

First is the personal and, if I dare to say, universal issue of what to do after a university degree in Spain and in any society that permits access to such a resource to the younger generations. I am of the opinion that the individual has the personal responsibility to explore all possible avenues to permit the full realization of his/her human potential. Thus, the issue of 'what to do next ', and not to be content with the 'routine path' should be important to any responsible young man or woman in a society. The adventure of science and the quest to understand the world that surround us will continue to satisfy our curiosity as human beings, and also to explore ways in which we can improve and sustain human life within the confines of planet Earth or beyond. There will always be new frontiers for the younger minds to discover by themselves and to participate in the collective endeavor. Each one of them will have to find his/her way to find out what they would like to do with their lives for their personal and societal fulfillment.

Second is the role that the social environment itself, where we are born and mature, should play in fulfilling our personal dreams. The availability of resources and the social milieu are constantly changing and a prosperous society today may turn out to be financially dependent tomorrow. And this applies to the strictly economical factors as well as the cultural factors: one cannot assume that science will always be supported as a social endeavor, at least not on the continuously growing pace that we scientist would like to see.
In the early seventies, I found the need to leave Spain and make my life somewhere else for intellectual and economic reasons. Unfortunately, I feel that putting aside the general views about the Spanish society that I expressed earlier, several aspects of the economic, cultural and societal milieu of Spain still remain the same. Thus, the younger generations of trained scientists, engineers and technically competent youths still have to leave Spain to be able to realize their full potential, as I did half a century ago. In my view, this is a reflection of the fact that many of the malaises of the academic and research institutions of Spain that I encountered nearly half a century ago, are still present and they do not fulfill their role adequately, in spite of the hard work and dedication of their members.

In addition, the technical and economic fabric of the Spanish society is still not able to absorb the larger number of university graduates resulting from the expansion of the institutions of higher education. Indeed, the administration (of either party) is partly to blame for this. Science and the scientific activity are not a part of the societal culture or political decision making of Spain. The science and research that is currently done at universities and research institutions of the country does not impact the lives of their citizens. Most (if not all) of the technological innovations that reach the citizens of Spain are invented, designed and manufactured elsewhere, possibly even invented or designed by Spanish citizens but is certainly not originating in Spanish soil.

I do hope that these reflections that were prompted by the celebration of the IYCr2014, are of some value to the younger generations of students and scientists in Spain and possibly to some visionary science administrators or political figures. The future does belong to the younger generations but they need to find ways to fulfill their human potential for their own satisfaction and for the enrichment of their societies and of all humankind. I would like to end this perspective and these reflections with my slightly revised versión (insert in parenthesis) of M.G. Rossmann's quotation that in retrospect has been a compass during my professional and personal life:

'There are two reasons why we do research: One is the personal enjoyment of discovery (and the satisfaction of realizing our own human potential). The other is wanting to contribute something to humanity and to human knowledge'. 


\section{ADDENDUM}

X-Ray Diffraction In The First Half Of The $20^{\text {th }}$ Century In Spain

The preparation of the adjoined contribution prompted a systematic reading on various sources, trying to learn more about the beginnings of crystallography in Spain in the first half of the $20^{\text {th }}$ century. Fortunately, the International Union of Crystallography (IUCr) has historically published several books and articles in its official journal Acta Crystallographica, founded in 1948 to link the researchers using methods related to the use of X-rays in any domain of the sciences.

Among the many books and articles published, there is one that I treasure. It was published in 1962 by the IUCr precisely to commemorate the fiftieth anniversary of the diffraction experiment inspired by Laue and performed by Friedrich and Knipping in Munich in that momentous year of 1912. The book was edited by P.P. Ewald and contains contributions from numerous crystallographers. The volume is remarkable in that it reviews the status of the fields of X-ray diffraction, structural analysis, and X-ray Spectroscopy by many (unfortunately not all) of the pioneers in the fields. In addition, in the second half, the editor purposely attempts to resonate a more personal note:

"There is nowadays, a general demand for more of the human touch in the presenting of science to the coming generation, for more detail about the men whose memory is handed down by the laws named after them [...] whose personality is effaced as the circle of their students fades out"

Thus, in the second part, there are three major sections devoted to personal reflections. First, one dedicated to the people who had recently passed away (In Memorian of M. von Laue, P. Knipping, W. T. Astbury, W.H. Bragg, Carl H. Hermann, R.E. Franklin an others) and later a second one of personal reminiscences of researchers still very prominent in the field such as J.D. Bernal, J.M. Bijvoet, W.L. Bragg, K. Lonsdale and many others. The IUCr published this volume electronically in 1999 in commemoration of the XVIII Congress of the IUCr in Glasgow and I would suggest that you browse through it and see if there are any sections that pique your curiosity. In the spirit of the personal touch of this communication, I should add that I purchased my personal copy of this treasured volume from a 'used book sale' at the bookstore of the California Institute of Technology in 2011, while visiting to attend the Ph.D. defense of our son Pablo. It had been 'withdrawn from the Chemistry Library of the California Institute of Technology' and I dream that it might had been read and used by Linus Pauling himself (see Figure 11).

In between those personal sections that I mentioned earlier, there is a section devoted to trace down the development of crystallography in many laboratories around the world. To my good fortune, there is a summary section reviewing the expansion of $\mathrm{X}$-ray diffraction methods worldwide written by Ewald himself with a concise section dedicated to Spain (pgs. 502-503). I will use this summary as a framework to briefly review the history of the introduction of crystallography in Spain from 1912 to 1960.

Figure 11. First page of the book published in 1962 to commemorate the discovery of X-ray Diffraction. Personal copy of the author with markings from the previous owner of the book, the Chemistry Library of the California Institute of Technology. The seal is still visible.

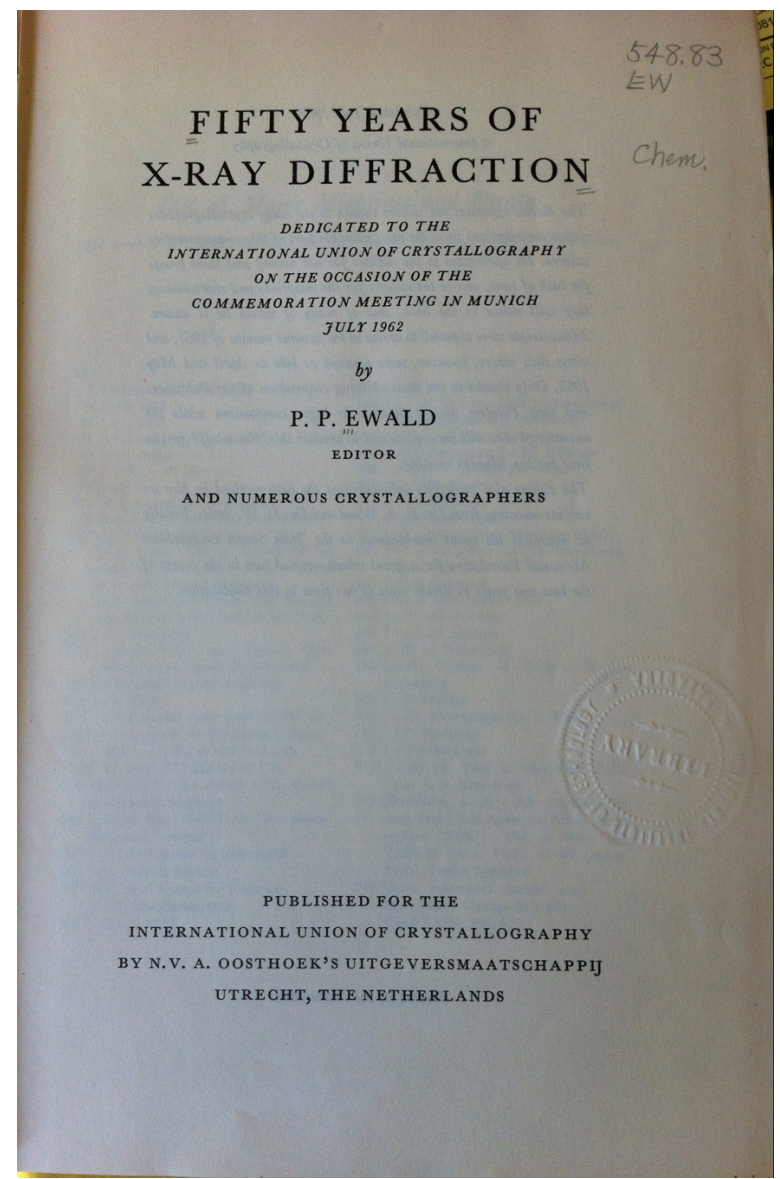


Ewald writes that soon after the communication of the results of Laue, Friedrich and Knipping there were two communications to the Spanish scientific community, one by F. Pardillo en el Boletín de la Real Sociedad de Historia Natural (Pardillo, 1913) one year after the original publications, and another two years later by Blas Cabrera in the Anales de la Sociedad Española de Física y Química (Cabrera, 1915a). Driven by intense curiosity, I decided that I should read these communications to see how the scientific community had received the remarkable results from the German scientists and add them to my perspective on the development of macromolecular crystallography.

The communication by Pardillo is what that I expected: a brief and enthusiastic summary of the results directed to the scientific community, mostly focused in Geologists and Mineralogists. In his own words

"En el Instituto de Física teórica de la Universidad de Munich, se han realizado a principios del corriente año una serie de experimentos de tan gran importancia para la Cristalografía, que no puedo sustraerme al deseo de contribuir a divulgarlos, aun entre aquellos que no cultivan esta ciencia, pues son en último caso testimonios de las sublimes creaciones de la mente humana que preveen y suplen lo que ni los sentidos ni casi los medios auxiliares de experimentación permiten conocer"

Pardillo reviews the development of the reticular hypothesis to explain the internal structure of crystals based on the Bravais concepts and the mathematical propositions of Schönflies and Federov to conclude: "Realmente eran estudios abstractos destinados a explicar las dos cualidades de la materia cristalina: la homogeneidad y la simetría", with a very important caveat "La comprobación experimental más verosímil se encontraba en la exfoliación".

Then, he discusses briefly the hypothesis of the Xrays being wave-like and the approximate value of the its wavelength, as estimated by the physical ideas of the time, and the role of Laue in suggesting to $\mathrm{W}$. Friedrich the experiment of X-ray diffraction using crystals as diffraction gratings. He describes the experimental setting of Laue, Friedrich and Knipping and concludes enthusiastically:

"La teoría reticular, que encontró su primer campeón en Bravais, ha prestado, pues, a la Ciencia, simultáneamente, dos inmensos servicios: el descubrimiento de nuevas e importantes propiedades de los rayos Roentgen y dar verídica explicación a la estructura cristalina, demostrando al mismo tiempo que la cristalografía, aunque disciplina joven, camina con la seguridad y tiene el vigor y la energía de las ciencias adultas".

Indeed, introducing to the reader crystallography as a solid science for the future. There is no discussion of the later papers by the Braggs, regarding the use of this information to extract the atomic arrangement of the atoms inside the crystals.

The communication two years later by Blas Cabrera to the Anales, mentioned by Ewald, has a complete different character. The format is that of a thorough discussion and analysis of the most recent articles published in foreign journals of the physical sciences under the title 'Extractos de revistas'. In total there are four extensive contributions with a total of over hundred and forty pages, divided into seventy-three numbered sections (Cabrera, 1915a, 1915b, 1915c, $1915 d)$. Cabrera is in full command of the physical sciences of the time and presents a full account of the experiments of Laue and the German School, as well as the discoveries and methods of the British Schools of crystal structure analysis (W.H. and W.L Bragg). He also discusses with critical analyses the mathematical studies of X-ray scattering and diffraction, (having $\mathrm{J}$. J. Thomson, C.G. Darwin and R.W. James as its most prominent contributors) with an excellent coverage of the spectroscopy of X-rays that allowed the refining of the atomic model of Bohr (published in 1913), and the role that this spectroscopy played in ordering the periodic table of the elements based on the atomic number N. Although probably not widely recognized, it was this work that demonstrated that the most intrinsic property of the atomic structure was the atomic number $\mathrm{N}$, and not the atomic weight as had been originally proposed by Mendeleev in ordering the elements in periodic table. This was expressed by the formula derived by H.G.J. Moseley: $n=n_{0} A(N-b)^{2}(n$ is the emission frequency of the $\mathrm{X}$-rays for the element, $\mathrm{N}$ its atomic number and $\mathrm{A}$ and $\mathrm{b}$, constants).

The discourse is clear and penetrating. It is important to note from the discussion on the nature of $X$ rays the importance that it was assigned to the analogous properties of $\mathrm{X}$-rays and $\mathrm{\gamma}$ rays, obtained from the radioactivity effects (part I). He also discusses the enunciation of Bragg's Law and the equivalence between Laue's and Bragg's explanations of the first diffraction phenomena as observed in the Zinc blend crystals (section 12), and the importance of the intensity of the diffraction at each diffraction maxima as the critical parameter to distinguish the different atoms in the cubic lattices. At the time, measuring 
the intensities could only be done with the spectrometer designed by W.H. Bragg. He goes on to explain the derivation of the first structures of halides with the importance of the structure of diamond derived by the Braggs in 1913. There are many gold nuggets all through the discussion mostly extracted and explained from the original papers but there are also some that are personal insights.

After this magisterial dissertation on the new sciences of crystallography, X-ray diffraction, X-ray structural analysis and X-ray spectroscopy, Cabrera concludes his contributions with:

"He dejado volar un poco la imaginación en estos últimos apartados, con el fin de marcar con los más vivos colores el enorme interés que encierra el estudio de este capítulo de la Física, llamado en plazo no lejano a determinar la estructura íntima del átomo, con tanta seguridad acaso como hoy podemos describir la de nuestro sistema planetario".

In spite of these enthusiastic reports and 'proclamations' of the significance and value of these theoretical, experimental and technical discoveries in the rest of Europe, it took another ten years before the experimental techniques related to $\mathrm{X}$ ray diffraction entered in Spain. First at the Physics Department of the University in Madrid and later at the Instituto Nacional de Física y Química that was established by the Rockefeller Foundation in 1932, in what is now the Instituto de Química Física Rocasolano. It is important to recognize the premier status of Blas Cabrera among the great scientific minds of the time, as has been documented in the brief article available recently from the web (http://www.agenciasinc.es/Reportajes/Blas-Cabrera-el-gran-fisico-espanol-amigo-de-Einstein). From the above discussion, it should be clear that he played a very important role in introducing to the scientific community in Spain, the theory and experiments related to X-ray Diffraction as he had done for relativity before.

At the Instituto Nacional de Física y Química Julio Palacios carried the torch of X-ray diffraction studies with a group of eager young students. A Weissenberg camera was built and the work pursued by Luis Brú, Julio Garrido and others. Unfortunately, the Civil War brought these efforts to a screeching halt in 1936 as well as the efforts that F. Pardillo had initiated independently in the mineralogy department of the University of Barcelona with very limited resources. Cabrera was among the significant group of Spanish scientists that surged from the early $20^{\text {th }}$ century to the Civil War, many of them formed in European universities and internationally recognized, among them Ramón y Cajal (1852-1934), Rey Pastor (1888-1962), Negrín López (1892-1956) and many others (CortijoMérida, 2011).

The end of the Spanish Civil War and the creation of the Consejo Superior de Investigaciones Científicas (CSIC) brutally annihilated the promising prospects envisioned only ten years earlier. Many prominent figures were exiled and there was a tight control of university appointments. Financial resources were very limited and accessible only to selected groups without regard to scientific prominence. The buildings and resources of the Junta de Ampliación de Estudios were transferred to the newly created CSIC, whose priorities were more related to political orthodoxy than scientific excellence (Gallo, 1972).

In the X-ray diffraction field, there was a revival after WWII headed by L.Brú, first from the University of La Laguna and later from the University of Sevilla in 1949 moving finally to Madrid. Among Spanish crystallographers is worth mentioning José Luis Amorós who graduated from the University of Barcelona and worked at the Instituto Lucas Mallada (part of the CSIC) and later became professor of crystallography in Madrid. He worked and published extensively in what was later called 'molecular crystals', as opposed to the ones of inorganic salts that were the cornerstones of the development of crystallography in the early years.

Finally, Ewald mentions the publication of the book Los rayos $X$ y la estructura fina de los cristales; fundamentos teóricos y métodos prácticos authored by J. Garrido and J. Orland that was a very valuable introduction to the subject as well as to the contributions by the authors. A Crystallographic Society was formed in 1950 with about 35 members, its membership reaching sixty a decade later.

An extensive conceptual and historical analysis of the development of the science of crystallography in Spain, before and after the critical experiments of W. Friedrich, P. Knipping and M. Laue has been published in the Bol. R. Sociedad Espanola de Historia Natural (Seccion Geologia) (2005), 100 (1-4): 25-37 written by Prof. Juan Manuel Garcia Ruiz. The author regrets not having discussed this contribution within the context of this brief addendum. 
I will finish this addendum with a bibliographic recommendation. For a detailed presentation of the early days of X-ray Diffraction and its impact in the development of modern physics, chemistry, mineralogy, biology and other branches of science, I can recommend the recently published book by one of the pioneers in France A. Authier The Early Days of X-ray Crystallography (Authier, 2014). This book expands and complements the content of the original book edited by P.P. Ewald.

\section{ACKOWLEDGEMENTS}

The author greatly appreciates the courtesy of the editor of this special issue of Arbor (José Miguel Mancheño) and the staff of the CSIC libraries for invaluable help in obtaining copies of the original reports of $\mathrm{F}$. Pardillo and B. Cabrera from the library of the CSIC. Without their assistance it would had been impossible to reveal the contributions of Pardillo, Cabrera and the many other Spanish scientists involved in the development of Crystallography and X-ray Diffraction in Spain during the first half of the $20^{\text {th }}$ century.

\section{NOTES}

1. Some of the personal experiences related in this essay have been described in more detail in the personal narrative presented in Crystals and Life: A Personal Life (Abad-Zapatero, 2002a). Specific references to portions or chapters of this work will follow.

2. A full account of these events by the protagonists has been given in the excellent book edited by P.P. Ewald (1962) in commemoration of Fifty Years of $X$ ray Diffraction. This volume is a treasure for anyone interested in the early years of the field for its technical and personal content.

3. Abad-Zapatero (2002a, pp. 211-213)

4. A detailed account of the impact that the work of W. M. Stanley caused in the scientific and cultural media of the time has been presented in Kay (1986). It is certainly worth reading in the context of the origins of structural biology.

5. Bernal and Fankuchen were able to show that Stanley's TMV crystals were only sheaves of virus particle aligned roughly parallel. They were able to obtain much better ordered para-crystalline samples (oriented gels) that later permitted the determination of the full structure of TMV by the group of Rosalind Franklin including several pioneers of structure biology: A. Klug, D. Caspar and $\mathrm{K}$. Holmes among others (see Watson, 1971, p. 433).

6. See Watson, 1971, p. 495.

7. I found this observation of Crick quite intriguing and possibly useful for the younger people trying to find their future careers and interests. See Ridley (2006, p. 23)
8. I have written about the impact that this book had on me upon my arrival to the USA in a brief reflection on the ACA Newsletter (Abad-Zapatero, 2011) and also Abad-Zapatero (2012a).

9. The contributions of M. G. Rossmann to the methodology and achievements of Structural Biology are enormous. Fortunately, World Scientific has published a selection of his scientific articles recently in an attractive volume (Rossmann, 2014). This note refers to paper no. 62 of the collection, published in 1973. The reader can find many of the references of this perspective within this volume.

10. It is impossible to describe in a few paragraphs the excitement of those years. Some details of the experiences and methods can be found in chapter 7 and throughout the book Crystals and Life: A Personal Life (Abad-Zapatero, 2002a).

11. This is paper no. 121 in the Rossmann collection mentioned above. A key paper in the methodology of processing diffraction data obtained with the oscillation photography method. An example of the appearance of these diffraction patterns can be found in Figure $6 \mathrm{~b}$. This is currently the standard method of data collection at synchrotron sources. In the early photos it was important to orient the crystallographic axis with respect to the X-ray beam. Nowadays this is not important (see note 14).

12. Abad-Zapatero (2002a, chapter 22, pp. 169-177). The full text of 'The Ballad of the $2.8 \AA$ of SBMV' was published in Journal of the Sociedad Española de Virología in 2013. I am grateful to Carlos Briones for the invitation to publish the full text. A black and white photograph of the SBMV model being built in the Richard's Box at Purdue can be seen in Abad-Zapatero (2002a, Chapter 11, p. 83).

13. A bureaucratic issue needs to be clarified here. I had been in the USA for twelve years on J-1 visas that are nonemigrant visas and do not permit USA citizenship. Unable to find an academic or research job in Spain, in the Fall of 1983 I re-entered the US with the family with an emigrant visa. This could permit the application for USA citizenship in seven years.

14. Another methods contribution by Rossmann. This corresponds to paper no. 170 in the collection above (Rossmann and Erickson, 1983).

15. Many of the scientific papers related to the structures of HRV14 and poliovirus, including its relationship to the fold of the plant viruses (SBMV), are included in the collection of Rossmann's papers mentioned above (nos. 183, 193 and many others) including the formulation of the canyon-hypothesis for virus attachment.

16. Abad-Zapatero (2002a, chapter 15) for more details of the initial work that made possible the structure of the ribosomes at high resolution.

17. See for instance paper no. 472 in the collection referring to the structure of the mature dengue virus ( $\mathrm{Li}$ et al., 2008).

18. I have discussed my fascination with these problems in chapters 25 and 26 of Crystals and Life. There is much that still needs to be done and explored by the future generations to better understand what life is at the molecular and atomic level. 


\section{REFERENCES}

Abad-Zapatero, C., Abdel-Meguid, S. S., Johnson, J. E., Leslie, A. G. W., Rayment, I. Rossmann, M. G., Suck, D. and Tsukihara, T. (1980). Structure of southern bean mosaic virus at $2.8 \AA$ resolution. Nature, 286, pp. 33-39.

Abad-Zapatero, C., Griffith, J. P., Sussman J. L. and Rossmann, M. G. (1987). Refined crystal structure of dogfish $M_{4}$ apo-lactate dehydrogenase. Journal of Molecular Biology, 198, pp. 445467. http://dx.doi.org/10.1016/00222836(87)90293-2

Abad-Zapatero C., Goldman, R., Muchmore, S. W., Hutchins, Ch., Stewart, K., Navaza, J., Payne, C. D. and Ray, T. L. (1996). Structure of a secreted aspartic protease from C. albicans complexed with a potent inhibitor: implications for the design of antifungal agents. Protein Science, 5, 4, pp. 640-652.

Abad-Zapatero, C. (2002a). Crystals and Life: A Personal Journey. La Jolla, CA: International University Line.

Abad-Zapatero, C. (2002b). Protein Crystallography is Dead: Long Live Protein Crystallography. Zeitschrift für Kristallographie, 217, pp. 1-3.

Abad-Zapatero, C. (2005). Notes of a Protein Crystallographer: My nights with ACTOR. Acta Crystallographica, D61, pp. 1432-1435. http://dx.doi. org/10.1107/S090744490502473X

Abad-Zapatero, C., Perišić, O., Wass, J., Bento, A. P., Overington, J., Al-Lazinkani, B. and Johnson, M. E. (2010). Ligand efficiency indices for an effective mapping of chemico-biological space: the concepts of an atlas-like representation. Drug Discovery Today, 15, pp. 804-811. http://dx.doi.org/10.1016/j. drudis.2010.08.004

Abad-Zapatero, C. (2011). Notes of a Protein Crystallographer - Cold Spring Harbor Meeting in 1971 revisited: a commemoration of the birth of the Protein Data Bank (PDB40). ACA RefleXions, 4, pp. 24-25.

Abad-Zapatero, C. (2012). Notes of a Protein Crystallographer: On the high resolution of the PDB deposition rates. Acta Crystallographica, D68. pp. 613-617. http://dx.doi.org/10.1107/ S0907444912004799

Abad-Zapatero, C. (2013a). Poema a la estructura de un virus. Ballad of the 2.8
Å Structure of SBMV. Virología, 16, 3, pp. 66-69.

Abad-Zapatero. C. (2013b). Ligand Efficiency Indices for Drug Discovery. Towards an Atlas-Guided Paradigm. Academic Press.

Abad-Zapatero, C. (2014). Notes of a Protein Crystallographer: The Beauty of the Rose Windows and the different meanings of Symmetry. Acta Crystallographica, D70, pp. 907-911. http://dx.doi. org/10.1107/S1399004713032859

Authier, A. (2014). Early Days of X-ray Crystallography. Oxford: Oxford University Press.

Bernal, J. D. and Crowfoot, D. (1934). X-ray Photographs of Crystalline Pepsin. Nature, 133, pp. 794-795. http://dx.doi. org/10.1038/133794b0

Cabrera, B. (1915a). Estado actual de la teoría de los rayos $X$ y $Y$ : su aplicación al estudio de la estructura de la materia. Anales de la Sociedad Española de Física y Química, 13, 7. Part I. Sections 1-16, pp. 7-30.

Cabrera, B. (1915b). Estado actual de la teoría de los rayos $X$ y $\mathrm{y}$ : su aplicación al estudio de la estructura de la materia. Anales de la Sociedad Española de Física y Química, 13, 7. Part II. Sections 17-29, pp. 63-87.

Cabrera, B. (1915c). Estado actual de la teoría de los rayos $X$ y $\gamma$ : su aplicación al estudio de la estructura de la materia. Anales de la Sociedad Española de Física y Química, 13, 7. Part III. Sections 30-47, pp. $129-172$

Cabrera, B. (1915d). Estado actual de la teoría de los rayos $\mathrm{X}$ y $\mathrm{y}$ : su aplicación al estudio de la estructura de la materia. Anales de la Sociedad Española de Física y Química, 13, 7. Part IV. Sections. 48-73. pp. 184-235.

Cortés-Cabrera, A., Morreale, A., Gago, F. and Abad-Zapatero, C. (2012). AtlasCBS: a web server to map and explore chemico-biological space. Journal of Computer-Aided Molecular Design, 26, pp. 995-1003. http://dx.doi. org/10.1007/s10822-012-9587-5

Cortijo-Mérida, M. (2011). Veinticinco Años de la Sociedad de Biofisica de España (1986-2011). Murcia, pp. 30-31.

Ewald, P. (ed.) (1962). Fifty Years of X-ray Diffraction. Utrecht: International Union of Crystallography. http://dx.doi. org/10.1007/978-1-4615-9961-6
Gallo, M. (1972). Historia de la Universidad Española. En Historia de la España franquista. París: Ruedo Ibérico.

García-Ruiz, J. M. (2005). El papel de la cristalografía en los estudios de Historia Natural. Boletín de la Real Sociedad Española de Historia Natural (Sección Geológica), 100, pp. 25-37.

Garrido, J. y Orland, J. (1946). Los rayos $x$ y la estructura fina de los cristales; fundamentos teóricos y métodos prácticos. Madrid: Dossat.

Jones, T. A. (1978). FRODO: A graphics model building and refinement system for macromolecules. Journal of Applied Crystallography, 11, p. 268. http://dx.doi.org/10.1107/ S0021889878013308

Kay, L. E. (1986). W. M. Stanley's Crystallization of the Tobacco Mosaic Virus, 19301940. Isis, 77, 3, pp. 450-472.

Li, L., Lok, S-M., Yu, I-M., Zhang, Y., Kuhn, R. J., Chen, J. and Rossmann, M. G. (2008). The flavivirus precursor membrane-envelope protein complex: structure and maturation. Science, 319, pp: 1830-1834.

Luo, M., Vriend, G., Kamer, G., Minor, I., Arnold, E., Rossmann, M. G., Boege, U., Scraba, D. G., Duke, G. M. and Palmenberg, A. C. (1987). The atomic structure of Mengo virus at $3.0 \AA \AA$ resolution. Science, 235, pp. 182-191.

Pardillo, F. (1913). Descubrimientos recientes sobre la estructura de los cristales. Boletín de la Real Sociedad de Historia Natural, 13, pp. 336-339.

Phillips, D. C. (1966). The Three-dimensional Structure of an Enzyme Molecule. Scientific American, 215, pp. 78-90. http://dx.doi.org/10.1038/scientificamerican1166-78

Rao, S. T. and Rossmann, M. G. (1973). Comparison of super-secondary structures in proteins. Journal of Molecular Biology, 76, pp. 241-256. http://dx.doi. org/10.1016/0022-2836(73)90388-4

Ridley, M. (2006). Francis Crick. Discoverer of the Genetic Code. New York: Harper Collins Publishers.

Rossmann, M. G. (1979). Processing oscillation diffraction data for very large unit 
cells with an automatic convolution technique and profile fitting. Journal of Applied Crystallography, 12, pp. 225-238. http:// dx.doi.org/10.1107/S0021889879012218

Rossmann, M. G. and Erickson, J. W. (1983). Oscillation photography of radiationsensitive crystals using a synchrotron source. Journal of Applied Crystallography, 16, pp. 629-636. http://dx.doi. org/10.1107/S002188988301119X

Rossmann, M. G., Arnold, E., Erickson, J. W., Frankerberger, E. A., Griffith, J. P., Hecht, H. J., Johnson, J. E., Kamer, G., Luo, M. and Moser, A. G. (1985). Struc- ture of a human common cold virus and functional relationship to other picornaviruses. Nature, 317, pp. 145-153. http://dx.doi.org/10.1038/317145a0

Rossmann, M. G. (2014). Selected Papers of Michael G. Rossmann with Commentaries. The development of Structural Biology. London: World Scientific.

Setlow, R. B. and Pollard, E. C. (1962). Molecular Biophysics. London and Palo Alto: Addison-Wesley.

Stanley, W. M. (1935). Isolation of a crystalline protein possessing the proper- ties of tobacco-mosaic virus. Science, 81, pp. 2113-2114. http://dx.doi. org/10.1126/science.81.2113.644

Watson, J. (coord.) (1971). Structure and Function of Proteins at the ThreeDimensional Level. Cold Spring Harbor Symposia on Quantitative Biology, XXXVI.

Yonath, A., Müssig, J., Tesche, B., Lorenz, S., Erdmann, V. A. and Wittmann, H. G. (1980). Crystallization of the large ribosomal subunit from $B$. stearothermophilus. Biochemistry International, 1, pp. 315-428. 